\title{
On the Developmental Timing of Stress: Delineating Sex-Specific Effects of Stress across Development on Adult Behavior
}

\author{
Anna Schroeder ${ }^{1,+}$, Michael Notaras ${ }^{2,+}$, Xin Du $^{1}$ (iD) and Rachel A. Hill ${ }^{1, *}$ \\ 1 Department of Psychiatry, School of Clinical Sciences, Monash University, Clayton 3168, Australia; \\ anna.schroeder@monash.edu (A.S.); xin.du@monash.edu (X.D.) \\ 2 Center for Neurogenetics, Brain \& Mind Research Institute, New York, NY 10065, USA; \\ mjn2004@med.cornell.edu \\ * Correspondence: rachel.hill@monash.edu; Tel.: +61-3-8572-2917 \\ + These authors contributed equally to this work.
}

Received: 31 May 2018; Accepted: 27 June 2018; Published: 29 June 2018

\begin{abstract}
Stress, and the chronic overactivation of major stress hormones, is associated with several neuropsychiatric disorders. However, clinical literature on the exact role of stress either as a causative, triggering, or modulatory factor to mental illness remains unclear. We suggest that the impact of stress on the brain and behavior is heavily dependent on the developmental timing at which the stress has occurred, and as such, this may contribute to the overall variability reported on the association of stress and mental illness. Here, animal models provide a way to comprehensively assess the temporal impact of stress on behavior in a controlled manner. This review particularly focuses on the long-term impact of stress on behavior in various rodent stress models at three major developmental time points: early life, adolescence, and adulthood. We characterize the various stressor paradigms into physical, social, and pharmacological, and discuss commonalities and differences observed across these various stress-inducing methods. In addition, we discuss here how sex can influence the impact of stress at various developmental time points. We conclude here that early postnatal life and adolescence represent particular periods of vulnerability, but that stress exposure during early life can sometimes lead to resilience, particularly to fear-potentiated memories. In the adult brain, while shorter periods of stress tended to enhance spatial memory, longer periods caused impairments. Overall, males tended to be more vulnerable to the long-term effects of early life and adolescent stress, albeit very few studies incorporate both sexes, and further well-powered sex comparisons are needed.
\end{abstract}

Keywords: stress; animal models; development; sex; behaviour; HPA-axis

\section{Introduction}

Within the neurosciences, stress is a ubiquitous phenomenon studied across multiple models, at various levels of analysis and with differing methods. One commonality in the study of stress is the understanding that it is an experiential phenomenon that is cognitively framed by perceptual cues, responded to via coping mechanisms, and is controlled by the reactivity of neuroendocrine systems.

Acute stress allows the body to recruit the energy and resources to cope with the situation. The persistence of stress (chronic stress), however, can have a hazardous effect on the body, increasing the risk of schizophrenia, depression, heart disease, and a variety of other illnesses [1,2]. The acute stress response, or "fight and flight" response, was first described by Walter Bradford Cannon early in the 20th century. Perceived stressors which challenged "homeostasis", a term Cannon coined, activate the sympatho-adrenomedullary system, resulting in the immediate release of catecholamines. 
As the name suggests, the immediate effect of the acute response is to marshal the body's resources to combat, or flee from, the immediate source of stress, by elevating heart rate, releasing stored energy to muscles, dilating blood vessels to muscles, and boosting metabolic rate [3]. In the brain, noradrenaline increases arousal and attention, as well as mediates memory formation and retrieval [4]. While noradrenaline has been shown to be necessary for attentional set-shifting [5], elevated levels have been shown to impair lexical-semantic and associative network flexibility [6]. Adaptation of the sympatho-adrenomedullary system occurs if the same stressor is repeatedly and predictably experienced, but upon novel stressors, the system reverts to high release of catecholamines $[7,8]$. Importantly, evidence shows that this acute stress response is also influenced by the slower central stress response system, the hypothalamic-pituitary-adrenal (HPA) axis [9]. Given the prevalent role of the HPA axis in regulating stress adaptation, its dysfunction has been heavily implicated in a wide variety of disorders [10].

The HPA axis modulates a multitude of bodily functions to adapt an organism to stressors in the environment. It self-regulates via a negative feedback loop. The HPA axis is activated by hypothalamic parvocellular neurons within the paraventricular nucleus, secreting corticotrophin-releasing factor (CRF) into the medial eminence, which in turn, triggers the release of adrenocorticotropic hormone $(\mathrm{ACTH})$ from the adenohypophysis of the anterior pituitary. ACTH reaches the adrenal glands via the bloodstream, and activates the synthesis and release, in the adrenal cortex, of cortisol in humans and corticosterone (CORT) in rodents into the systemic circuit, where they travel back to the brain to bind to their cognate glucocorticoid (GR) and mineralocorticoid (MR) receptors. Of note, a large number of studies have shown sex differences in the secretion of CORT under both basal conditions as well as in response to precursors of CORT, and a variety of psychological and physiological stressors [11]. It is generally believed that these sex differences result from differential regulatory effects of circulating gonadal hormones on HPA-axis activity. While estrogens sensitize the HPA-axis response to stressors and increase basal HPA-axis activity, testosterone has the opposite effects [11]. In agreement with this, gonadectomy in female rats attenuated HPA axis activity, whereas removal of testes increased basal HPA-axis activity in males [12]. Sex differences in neuroplasticity as a result of chronic stress have also been reported [13], which is likely related to differential stress responsivity and susceptibility to diseases in males and females. These are important findings that may contribute to explaining why stress-related disorders, such as depression, post-traumatic stress disorder (PTSD), and anxiety, are more prevalent in females [14-16]. Better understanding of the sex-specific mechanisms underlying these disorders will allow for more targeted and effective treatment options.

Interestingly, despite the well described sex differences with regards to stress reactivity [17], the majority of rodent studies use male rodents only to avoid female estrous cycle being a confounding factor.

GR and MR are highly expressed in brain areas involved in cognitive function, such as the hippocampus and the frontal cortex. Excitatory feedback of GR binding from the amygdala, or inhibitory feedback from GR binding in the hippocampus, back into the paraventricular nucleus then enhance or ceases the release of CRF, completing the feedback loop. Of note, the expression and regulation of GR, as well as the interaction of sex steroids with GR, are sexually dimorphic [18], which needs to be taken into account when interpreting results.

At the cellular level, stress has been shown to modulate many aspects of neuronal function, including dendritic spine morphology [19-23], synaptic transmission [24,25], and the expression of trophic factors, such as brain-derived neurotrophic factor (BDNF) [26-30]. According to length, degree of severity, and developmental period of exposure to glucocorticoid stress hormones, these alterations in neuronal physiology may benefit processing in the short-term, but implicitly impart vulnerability to pathology in the long-term by forcing the system into a permanent state of adaptation and compensation. Prolonged exposure to CORT was shown to reduce neurogenesis [31,32] and promote apoptosis of GR-expressing hippocampal neurons [33], and to cause morphological abnormalities in the prefrontal cortex (PFC) [34]. 
Recently, with Thomas Insel, the head of the National Institute of Mental Health, as well as the recently established Research Domain Criteria (RDoC), suggesting that mental disorders be regarded as "brain disorders" [35], the role of stress within the brain becomes more pertinent, given that many psychiatric disorders-particularly those of affect, anxiety, and psychosis-can be triggered by and modulated by stress exposure. Psychiatric disorders, such as schizophrenia and major depression, are thought to be disorders of neurodevelopment with origins in early (pre- and postnatal) life. The mean age of onset of major psychiatric disorders is typically during adolescence or early adulthood [36,37], and it is well accepted that brain regions associated with cognition and stress reactivity, such as the hippocampus or prefrontal cortex, are still undergoing maturation during these time points, [38]. Thus, aberrant development during critical periods may underlie or impart susceptibility to psychiatric symptomatology, and hence, the need to understand the role of stress during different periods of development is a priority.

Given the complex nature of different types of stressors and the body's differing responses to them, which are themselves compounded by a myriad of factors including genetics, environment (prenatal and postnatal) and sex, the study of stress and its fundamental effects in humans is extremely difficult. Rodent model is a tool that allows us to isolate and examine specific types of stressors at specific time points of development while minimizing genetic and environmental differences. This will allow us to uncover some important mechanisms of how stress can influence brain functions, which may offer knowledge important towards the treatment of human neurological disorders that are linked to stress. Keeping this in mind, the current review serves to evaluate the divergent behavioral effects of various types of stress, as modelled in rodents, during early, adolescent, and adult development. Due to the disparity in type, form, and length of stress treatments utilized between studies (see Figure 1), the discussion of physical, social, and pharmacological stress treatments will be separated to highlight important experimental outcomes of each form of stress when administered during different developmental periods. This review will particularly focus on long-term effects of stress on rodent behavior (such as cognitive function, depression- and anxiety-like behavior), as measured during adulthood. For the impact of stress on molecular changes, please refer to e.g., $[10,39,40]$. We will further outline the current understanding on sex differences in response to stress within each section of developmental time points, and emphasize their relevance in the respective context and the importance for future studies to differentiate and explore differences between the sexes, whereby important mechanistic insight may be gained. These effects of stress during early life, adolescence, and adulthood in males and females are summarized in Table 1. Given recent advancements in the accessibility of transgenic mouse lines, a brief discussion on how genetically modified rodent models can be utilized to delineate the behavioral effects of stress, with the GR and MR systems used as models. 


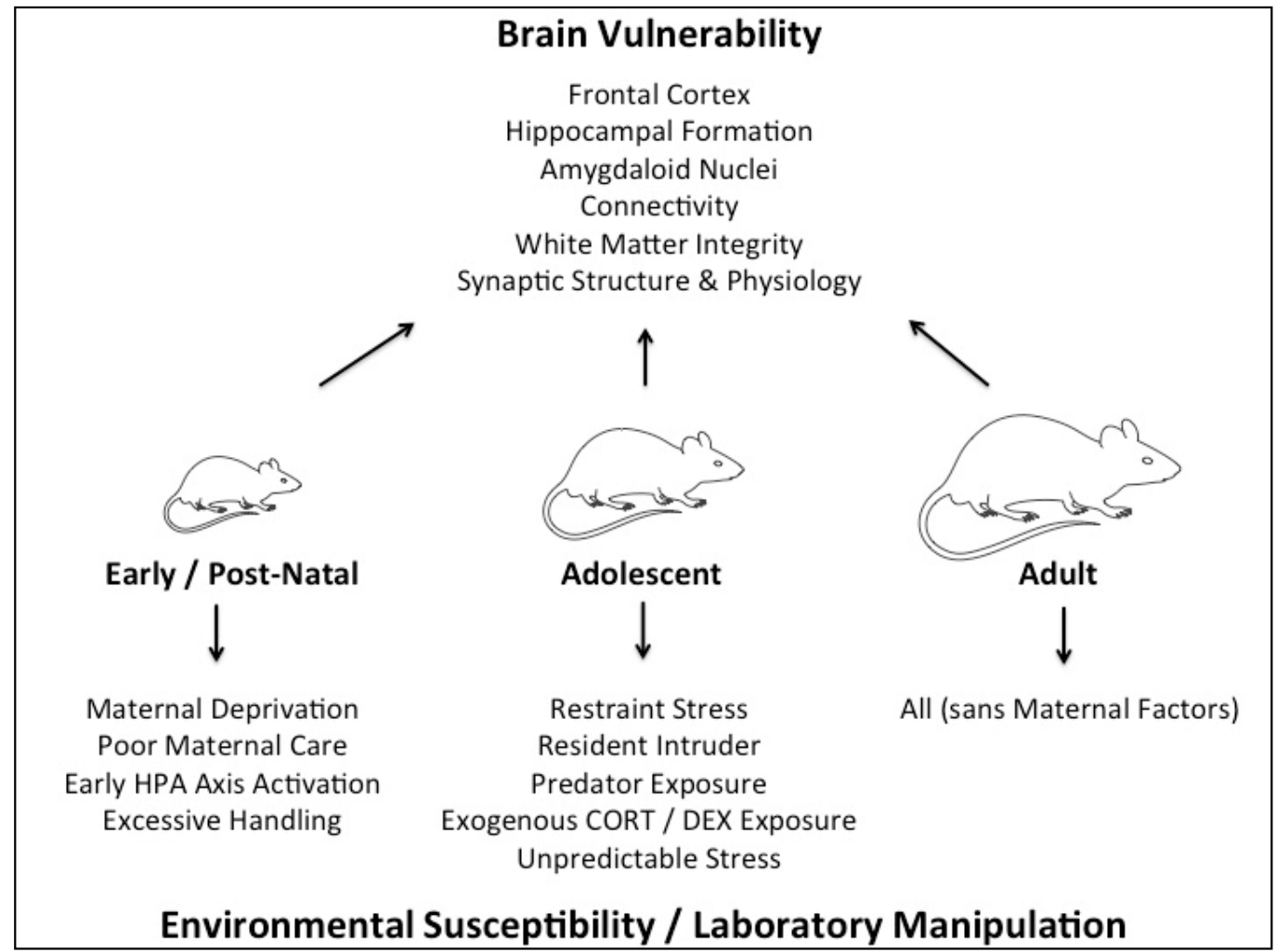

Figure 1. Divergence in the Modeling of Developmental Stress. The modeling of stress across development in rodents has been achieved using a range of different stress treatments, some which are specific to certain developmental periods (e.g., maternal deprivation during early development) while others can be applied independent of age (e.g., unpredictable stress). The length, severity, and type of stress can also be modulated to address relevant hypotheses. While "stress", especially that of the chronic form, may intrinsically affect regions of the brain with concentrated GR expression (e.g., the hippocampus), when stress occurs within different developmental windows, divergent behavioral effects may emerge, that can have differing value for the investigation of psychiatric endophenotypes. CORT = corticosterone; DEX = dexamethasone; HPA axis-hypothalamic-pituitary-adrenal axis.

Table 1. The effects of early, adolescent, and adult stress on behavioral and molecular phenotype in adulthood.

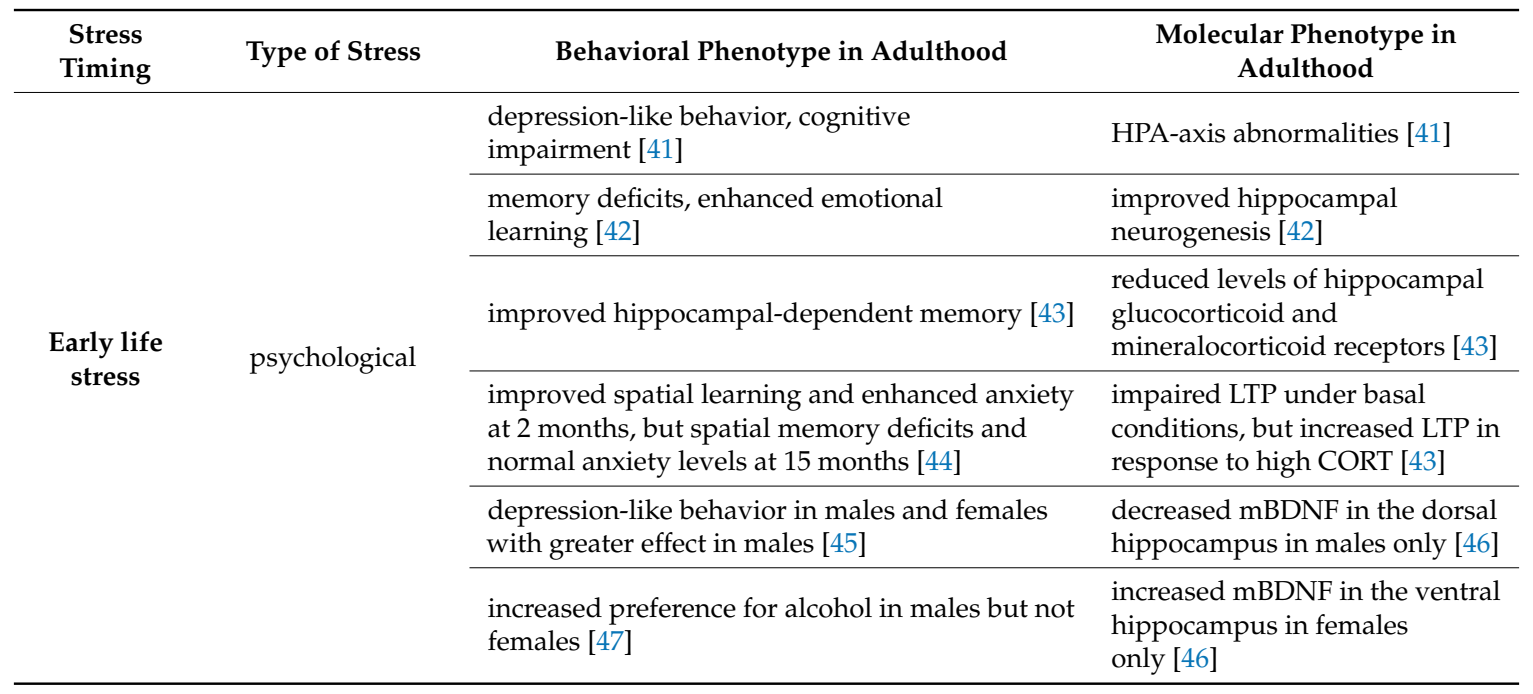


Table 1. Cont.

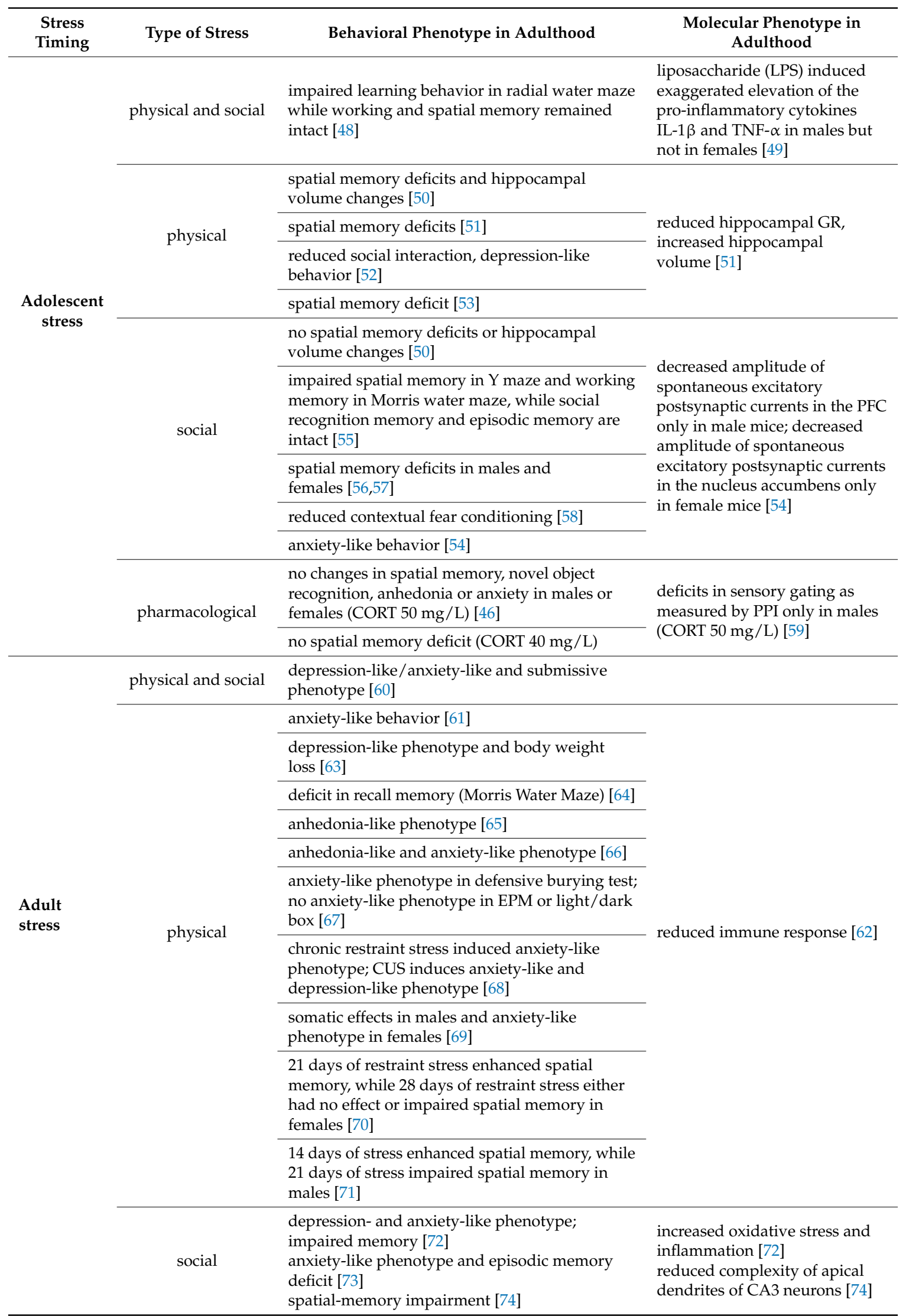


Table 1. Cont.

\begin{tabular}{|c|c|c|c|}
\hline $\begin{array}{l}\text { Stress } \\
\text { Timing }\end{array}$ & Type of Stress & Behavioral Phenotype in Adulthood & $\begin{array}{l}\text { Molecular Phenotype in } \\
\text { Adulthood }\end{array}$ \\
\hline \multirow{8}{*}{$\begin{array}{l}\text { Adult } \\
\text { stress }\end{array}$} & \multirow{4}{*}{$\begin{array}{l}\text { Disruptions to } \\
\text { normal circadian } \\
\text { rhythm (physical } \\
\text { and psychological) }\end{array}$} & depression-like and anxiety-like phenotype [75] & \multirow{4}{*}{$\begin{array}{l}\text { reduced dendritic length in the } \\
\text { DG and CA1 [76] }\end{array}$} \\
\hline & & no changes in memory or anxiety [77] & \\
\hline & & hippocampal memory deficit [78] & \\
\hline & & $\begin{array}{l}\text { anhedonia-like and depression-like phenotype; } \\
\text { learning and memory impairment [76] }\end{array}$ & \\
\hline & \multirow{4}{*}{ pharmacological } & depression-like phenotype [79] & $\begin{array}{l}\text { reduced hippocampal } \\
\text { neurogenesis }[80,81]\end{array}$ \\
\hline & & increased anxiety-like behavior [82] & increased apoptosis $[33,83,84]$ \\
\hline & & $\begin{array}{l}\text { depression-like phenotype in C57BL6/J but not } \\
\text { in C57BL6/N [85] }\end{array}$ & $\begin{array}{l}\text { reduced hippocampal } \\
\text { neurogenesis in males and } \\
\text { females [31] }\end{array}$ \\
\hline & & $\begin{array}{l}\text { enhanced emotionality score or no effect in } \\
\text { females [86] }\end{array}$ & $\begin{array}{l}\text { no changes in cell proliferation, } \\
\text { survival or neuronal maturation } \\
\text { in DG of the hippocampus in } \\
\text { females [86] }\end{array}$ \\
\hline
\end{tabular}

The effects of diverse types of chronic stress during early life, adolescence and adulthood in rodents are summarized. Blue color represents studies looking at only male rodents, while red color shows studies looking either at females only or at both sexes. Items in the right-most two columns are independent lists and are not linked to each other. CA1 = Cornu Ammonis 1; CA3 = Cornu Ammonis 3; CORT = corticosterone; $\mathrm{CUS}=$ chronic unpredictable stress; $\mathrm{DG}=$ dentate gyrus; $\mathrm{EPM}=$ elevated plus maze; $\mathrm{GR}=$ glucocorticoid receptor; $\mathrm{HPA}=$ hypothalamic-pituitary-adrenal axis; $\mathrm{LTP}=$ long-term potentiation; $\mathrm{mBDNF}=$ mature brain-derived neurotrophic factor; PFC = prefrontal cortex; PPI = prepulse inhibition .

\section{Early Life Stress Models}

Stress experienced during early life has a disruptive impact on the long-term outcome of an individual. During gestation, maternal stress is transmitted to the fetus via stress-related hormones, such as glucocorticoids. While it is beyond the scope of the current review, it is important to note that stress begins affecting the organism in utero. Despite being in the relatively cocooned environment of the womb, there is complex interplay between maternal genetics, offspring genetics, timing of stress, and the nature of stress, which together dictate the influence on offspring outcomes $[87,88]$. Prenatal stress can greatly impact upon the fetus and lead to permanent modification of the HPA axis, and stress responses later in life in a sex-dependent manner [87,89]. These results point to the significant role stress has, especially during critical phases of brain development, on the long-term function of the organism. Furthermore, the evidence underlines the fundamental role sex plays in mediating stress-induced effects, and advocates for the importance to include both sexes in rodent studies. After birth, the developing child faces many potential types of stressors, ranging from maternal deprivation or physical danger to psychosocial stressors, such as family conflict, neglectful parenting, or peer rejection. A large number of studies show that early stress becomes deeply embedded in the child's neurobiology, with profound long-term effects on cognition, emotion, and behavior [90-93]. Stress exposure during early life stages has been linked to increased risk for neuropsychiatric disorders, such as depression, autism, or schizophrenia [94]. In order to understand the importance of stress in the etiology of these disorders, and develop new therapeutic targets, a variety of animal models are used. While models of adolescent or adult stress involve physical/psychological, social, or pharmacological stress (as discussed in the next sections), early stress mainly involves psychological stress, including maternal separation (MS), early deprivation or isolation (ED), or early handling (EH). MS involves either a single 24-h separation of the intact litter from the dam, or repeated separations for a shorter, but prolonged period of 3-6 h/day [95]. EH involves daily human handling of pups to separate them from the mother, and usually also from the littermates, for a short time period, typically 15-30 min/day [95,96], and ED comprises repeated (typically daily) human handling of pups and separation from the mother and littermates for a prolonged period of 1-6 h/day [95]. Please note that 
other paradigms, such as physical stress during early life or pharmacological manipulations are used as well, but to a lesser degree at this life stage. Hence, in this section, we will focus on the psychological paradigms and their translational relevance. Furthermore, it is well known that early stress may cause age-dependent, differential behavioral outcomes [97]. This section will focus on animal models of neonatal stress and the long-lasting effect on behavior in adulthood, summarizing and evaluating current knowledge in the research of early stress.

\section{Psychological Stress Models in Early Life}

Studies by Seymour Levine have demonstrated that changes in the early postnatal environment (EH) can have lasting consequences for stress-responsiveness [98,99]. During this period, the presence of the dam is crucial for controlling activity of the HPA axis [100]. Alterations in HPA-axis activity can also be observed after a single separation for $24 \mathrm{~h}$ of male pups from the dam. Single $24 \mathrm{~h}$ MS in rats at postnatal day 3 (PD 3) resulted in increased basal CORT levels at 3 months of age, but this effect was not maintained into adulthood [101], while repeated MS for 3-6 h has been shown to affect HPA-axis responses into adulthood [102]. At the behavioral level, maternal separation has a profound effect on cognitive as well as emotional function. Male rats subjected to MS ( $3 \mathrm{~h}$ daily for the first 3 weeks) showed depressive-like behavior, as well as cognitive disruption accompanied by HPA-axis abnormalities in adulthood [41]. Supporting this data, Oomen et al. [42] also demonstrated spatial memory deficits in adult male rats after MS on PND3, however, this study further found that MS improved hippocampal neurogenesis and emotional learning under high stress conditions. These observations show that adverse early life events do not necessarily evolve into overall impaired hippocampal function later in life, but may provide resilience for optimal performance under stress in adulthood. Similarly, Champagne and colleagues [43] demonstrated that male adult low licking and grooming (LG) offspring displayed enhanced memory relative to high LG offspring, when tested in a hippocampal-dependent, contextual fear-conditioning paradigm. Hippocampal levels of glucocorticoid and mineralocorticoid receptors were reduced in low, compared with high LG offspring. Interestingly, low LG offspring, in contrast to those of high LG mothers, displayed significantly impaired long-term potentiation (LTP) under basal conditions, but surprisingly, a significantly enhanced LTP in response to high CORT in vitro. Furthermore, rats exposed to chronic stress in adulthood showed reduced immobility time in the forced swim test if previously exposed to neonatal handling, and this was accompanied by reduced neurochemical $\mathrm{Na}^{+}, \mathrm{K}^{+}$, and ATPase activity in the hippocampus, but increased activity in the amygdala [103]—-thus, the amygdala, in particular, may adopt resilience to previous stress exposure. This aligns with human studies whereby van Harmelen et al. [93] showed that early emotional maltreatment is associated with enhanced amygdala activity. Similarly, Lupien and colleagues [104] demonstrated that the amygdala is larger in children (boys and girls) raised by mothers suffering from depression. Hence, in agreement with animal studies, human studies report that while hippocampal-dependent cognitive function is impaired, emotional responsiveness, largely modulated by the amygdala, seems to be enhanced in adult individuals with a history of negative early life experience $[92,93,105]$. However, it is important to note that the extent of maladaptation or adaptation in response to early stress depends on the intensity, duration and type of stressor, genetic background, as well as the time point of testing (adolescence, adulthood). Protocols of early stress, animals, animal strains, time window of stress application, as well as the testing period and tests used, differ between laboratories, which makes it hard to draw conclusions on the effect of stress, per se. The definition of adolescent period or adulthood differs between studies and animals, which makes it difficult to compare outcomes. Furthermore, due to our highly dynamic biological nature, changing and adapting in response to the environment stimuli occurs every second. It is not enough to define, for example, adulthood as one fixed biological time point. Suri et al. [44] demonstrated differential effects of early stress (MS 3 h daily from PND2 to PND14) in early adulthood versus middle-aged rats. While ES animals in young adulthood ( 2 months) exhibited improved spatial learning and enhanced anxiety, the same animals showed normal anxiety levels, but long-term spatial 
memory deficits later in life ( 15 months). These behavioral changes were accompanied by hippocampal gene expression changes, which varied between the two time points. Hence, the memory improvement described by other studies may only comprise a small window in early adulthood while it declines with age.

Of note, all early stress animal studies summarized in this section used male rodents only while the majority of human studies generally use both males and females, and sometimes treat both sexes as one group. It is well established that males and females have different responses to stress as outlined in the introduction, and it is important to understand these differences in order to understand their impact on stress-related disorders and to establish well-targeted treatments. More recent studies have begun to focus on the effects of early stress on both males and females. Although the scope of this review is postnatal stress, it is important to mention that differential response to stress begins as early as in the placenta. A review by Perez-Cerezales and colleagues [106] nicely summarizes human and animal studies examining sex-specific responses to environmental stressors during both the periconception period (caused by differences in sex chromosome dosage) and placental development (caused by both sex chromosomes and hormones). In terms of postnatal early stress, Liu and colleagues [45] showed that witnessing maternal trauma between PD 21 and PD 27 (dam of offspring was exposed to an aggressive male rat 3 times a day for 7 consecutive days, while the offspring PD 21-27 was placed within proximity) induced behavioral despair phenotype in forced-swim test at PD 60 in both male and female offspring rats, with greater effects in male rats. Forced-swim test, as introduced by Porsolt and colleagues [107], measures behavioral despair, a "depressive-like" phenotype in rodents that is sensitive to a wide range of antidepressant drugs. In this test, rodents are placed into a beaker full of water for $6 \mathrm{~min}$, and their immobility time is recorded. It is believed that if mice "give up" earlier-meaning that they stop moving to try to escape-they are showing "depressive-like" symptoms of despair and helplessness. This forced-swim paradigm is sometimes also used as a stressor, which will be mentioned in section 3 (adult stress). Another study showed that male rats, following maternal separation during PD 1-7 for 15 min each day, exhibited increased preference for alcohol as compared to female rats during pubescent period and adulthood [47]. In our own laboratory, we previously subjected rats to early stress (MS) as well as adolescent stress (CORT treatment), singly or together, to delineate the effects of single stressors per se, and the combined effect of both stress insults on behavior, as well as molecular expression [46]. We showed that MS only decreased the expression of mature BDNF protein in male mice in the dorsal hippocampus, while BDNF was decreased in female mice in the ventral hippocampus in adulthood, showing sex-specific and region-specific effects of early stress on BDNF expression. BDNF plays an important role in hippocampal synaptic plasticity, neuronal migration, and protein synthesis-dependent long-term potentiation [108], and abnormal BDNF expression has been associated with depression and schizophrenia $[109,110]$. Albeit, no behavioral changes were seen after MS only, the combination of two stress insults (early and late) resulted in short-term memory impairment in males, while female rats showed anhedonia (inability to experience pleasure, a core symptom of major depressive disorder) as measured by the sucrose preference test, reflecting diverse manifestation of the same stressors between the sexes. Interestingly, a recent study in humans found that early adverse life events differentially affected male and female brains in terms of brain network architecture [111]. More sex-specific studies are needed to understand the sex-specific contribution of early life stress to the development of mental disorders, later in life.

\section{Adolescent Stress Models}

Adolescence is a transitional stage between childhood and adulthood with enormous physical and psychological changes, making it vulnerable to environmental insults, such as stress or drug abuse. It is well accepted that brain regions associated with cognition and stress reactivity, such as the hippocampus or prefrontal cortex, are still undergoing maturation during adolescence [38]. McCutcheon and Marinelli [112], for instance, showed that molecular mechanisms underlying long-term potentiation (LTP) differ in the adolescent period compared to both earlier life and adulthood. 
Hence, exposure to chronic stress during this critical period may result in persistent remodeling of brain structures critical for cognitive and emotional behaviors. A large number of reports link stressful life events, particularly during adolescence, with the onset of depression or other mental disorders, as well as drug use and cognitive impairment, suggesting it may be a triggering event $[38,90,113]$. Furthermore, it has been shown that periadolescent stress can affect stress responsiveness of the individual during and after pregnancy [114], thereby having the potential to affect stress adaptation in a transgenerational manner, through both behavioral and epigenetic modulation $[115,116]$. For example, maternal exposure to early life abuse has been linked to an increased risk in the offspring to various mental disorders, such as autism [117] and ADHD [118]. This is not surprising given evidence that the adolescent period is a time when the major endocrine system responsible for stress adaptation, the HPA axis, undergoes dynamic change in its regulation, both due to endocrine changes associated with puberty as well as in response to stressors [119]. For instance, while depression rates are roughly equal among prepubescent boys and girls, the rate increases dramatically once girls reach puberty, where, by age 15 , females are twice as likely as males to have had an episode of depression [120]. Importantly, in rats and mice, the HPA axis is still maturing during adolescence and differential HPA-axis response to stress has been shown during adolescence compared to adulthood [121], suggesting, firstly, that puberty is a key phase of development across species, and secondly, that rodents can be a valid model to investigate the various intricacies surrounding this dynamic stage in relation to stress.

Even though adolescence was considered to be human specific, many claim to distinguish an adolescent period in rodents based on changes in developmental trajectories during the peripubertal period, in behavior, such as increased risk taking; neuronal development in the frontal-cortical and limbic brain regions; and changes in gonadal hormone levels [38], similar to the human definition of adolescence [122]. Puberty in rodents (as well as humans) is well defined, with physical changes in sexual organs as well as hormones [123]. In female rats, puberty starts with vaginal opening (VO), which occurs around PD 30 and ends with the first estrous cycle around PD 40, indicating full establishment of hormones for sexual reproduction (reviewed in [123] (Figure 2)). In male rats, according to Fernandez-Fernandez et al. [124], sexual organ maturation begins with the sign of balano-preputial separation (BPS) around PD 40, and ends with the presence of mature spermatozoa and the completion of spermatogenesis around PD 60 (reviewed in [125] (Figure 2)). Similar biological processes defining puberty were observed in mice. While female mice show sexual maturation between PD 25 and 35, male mice show a later onset and longer period of puberty (PD 27-40) (reviewed in [125]).

In this section, we will briefly summarize the most recent insights into the models of adolescent stress. We will particularly focus on chronic stress during adolescence, and its long-lasting effects on cognitive performance. While early stress models mainly involve psychological stress, as described in the previous section, stressors used for adolescent animal models predominantly comprise physical, social, and pharmacological stressors, as outlined below. Once again, the majority of the studies used only male rodents, and only a few studies discriminated between males and females, which will be emphasized at the end of each section. 


\section{Puberty and adolescence in mice}
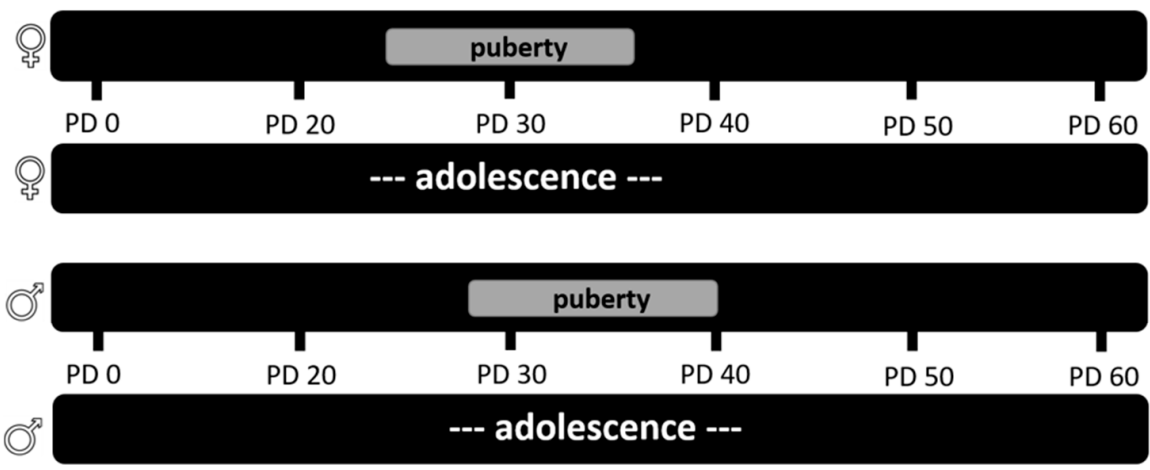

\section{Puberty and adolescence in rats}
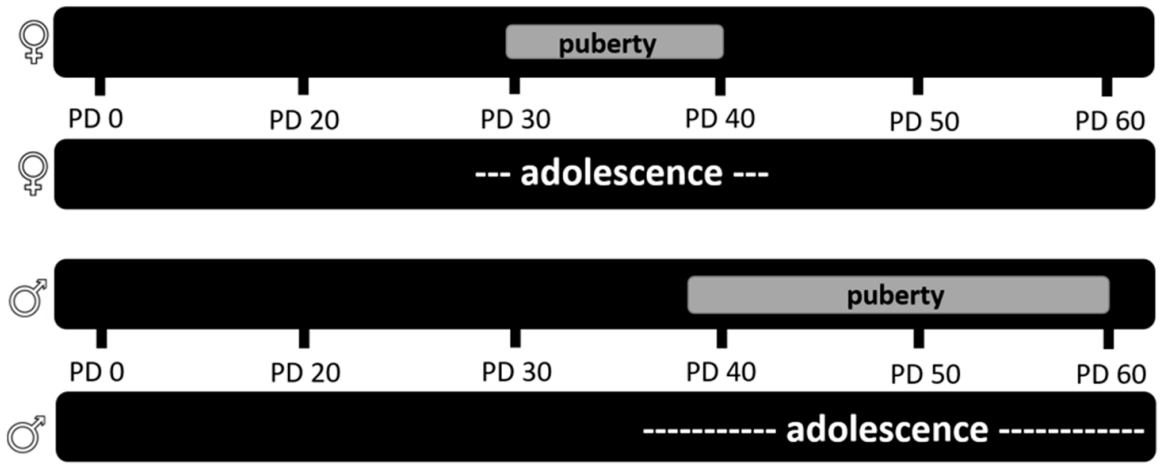

Figure 2. Puberty in male and female mice and rats. The timing of puberty and adolescence in male and female mice (top) and rats (bottom) (modified after [125]). PD = postnatal day.

\subsection{Physical and Social Stress during Adolescence}

Physical stressors used in animal research to date mainly include noise stress, foot shock, or circadian rhythm changes, while social stress is mimicked by social isolation, litter shifting, introducing new cage mates, or exposure to novel environments. In contrast to physical stress, psychological stress paradigms attempt to isolate the neurobiological aspect associated with fear and anxiety, rather than inducing direct physical challenges, such as discomfort or pain to elicit a stress response. One method is to expose rodents to predatory odors. Some researchers have gone further to expose rodents to actual predators, such as a cat [126,127]. Compared to other methods, researchers have argued that predator exposure is a more ethologically relevant inducer of stress that mimics emotional states related to fear and post-traumatic stress disorder in humans $[128,129]$.

Human studies showed that multiple unpredictable stressors were more predictive of psychiatric disorders than a single adversity alone [130]. Therefore, many studies apply a variety of unpredicted stressors in the animal research to strengthen the predictive validity and represent constructs that are more likely to mimic the human condition. Chronic unpredictable stress (CUS) can entail a range of either physical or social stressors, applied randomly, to inhibit habituation. A research group using a combination of physical and social stressors from PD 30-70 in male rats showed impaired learning behavior in these rats during adulthood when tested in the radial water maze, while working and spatial memory remained intact [48]. To discern potentially different effects between social and physical stressors, Isgor and colleagues [50] exposed rats to a variety of physical stressors (restraint, loud noise, cold exposure) or social stressors (isolation, novel environment, litter shifting) over four weeks from PD 26 to 58, and compared the effects of social CUS versus physical CUS on morphological and behavioral changes in these rodents. They demonstrated that three weeks after the last stressor, 
social-CUS animals did not show hippocampal volume changes or spatial memory deficits as opposed to the physical-CUS group. This indicates that the type of stressor is critical to cognitive performance later in life, and social stress according to this observation seems to affect spatial memory in rodents to a lesser degree, as compared to physical stressors. However, in a variation of chronic social stress, where new cage mates were introduced twice a week for 7 weeks beginning at day 32, impairments in spatial memory, as shown in the Y-maze and working memory in the Morris water maze, but not in an object or social recognition task, were found when tested one year after stress exposure [55], suggesting long-term effects of chronic social stress on aspects of memory.

Deficits in spatial performance were also shown in male and female rats after social instability stress ( $1 \mathrm{~h}$ isolation and change of cage mates daily from PD 30 to 45) [56,131]. Morrissey and colleagues [58] showed reduced contextual fear conditioning in rats exposed to social instability during adolescence, but not during adulthood. This suggests that the type of social stress and the timing plays a crucial role in determining whether it will affect a particular type of memory. In support of the study by Isgor et al. [50], claiming that physical CUS has a profound effect on spatial memory and hippocampal volume as mentioned above, exposure of rodents to physical variable stress resulted in reduced hippocampal GR receptor expression, as well as increased hippocampal volumes [51]. These morphological changes were associated with spatial memory deficits in adulthood [51]. Oztan et al. [52] demonstrated reduced social interaction and forced swim immobility, suggesting that adolescent exposure to physical CUS not only results in cognitive impairment, but also in depression-like behavior. Notably, the same stressors given in adulthood did not elicit such persistent morphological and behavioral changes (reviewed in [51]), suggesting the adolescent period to be specifically vulnerable to CUS.

Unfortunately, not many studies have looked at sex differences with regards to the effects of chronic adolescent physical and social stress on adult behavior. One study by Pyter and colleagues [49] investigated the effect of chronic stress on neuroimmune effects during adulthood in male and female rats. The neuroimmune system is highly interconnected with the endocrine stress system, and both are suggested to contribute to psychiatric disorders, such as major depression [132]. In this study, male and female rats underwent a chronic adolescent stress paradigm, in which experimental rats were exposed to randomized episodes of restraint stress and social defeat by same-sex aggressors. When challenged with the endotoxin liposaccharide (LPS) intraperitoneally in adulthood, male stress-exposed rats displayed exaggerated induction of the pro-inflammatory cytokines IL- $1 \beta$ and TNF- $\alpha$. Interestingly, females did not display a similar inflammatory response [49]. This study suggests males to be more vulnerable to adolescent stress than females, in terms of the immune response in the brain. A recent study exposed adolescent male and female C57BL/6J mice to chronic variable social stress (CVSS; repeated cycles of social isolation + social reorganization) or control conditions from postnatal days (PD 25-59) [54]. Anxiety-like behavior was measured in the elevated plus-maze at PD 61-65, and synaptic transmission in the prefrontal cortex (PFC) and nucleus accumbens (NAC) - brain regions that are implicated in anxiety and addiction-were assessed at PD 64-80. While both male and female mice developed anxiety-like behavior, stress decreased the amplitude of spontaneous excitatory postsynaptic currents in the PFC only in male mice, while these were decreased in NAC specifically in female mice. This study emphasizes sex-specific and brain region-specific differences in response to chronic adolescent stress. More studies are needed to better understand the involvement of sex hormones in response to stress on brain development in males and females.

Taken together, it appears that physical CUS, specifically during adolescence, but not during adulthood, has a more profound effect on spatial memory compared to social CUS, as measured in male rodents. Social CUS, however, can elicit memory impairment as well as depression-like behavior, dependent on the duration and type of CUS. The aforementioned sex-specific and brain region-specific differences in response to chronic adolescent stress further emphasize the need for more studies delineating differential effects of stress in males and females. 


\subsection{Pharmacological Stress During Adolescence}

The adrenal steroid hormone glucocorticoid (cortisol in humans and CORT in rodents) is a major stress hormone that has a range of physiological effects. Prolonged elevation of glucocorticoids, however, has been shown to be damaging to the brain, particularly in the hippocampus $[33,83,84]$. Administration of glucocorticoids has been used as a pharmacological model of stress, however, it is important to keep in mind that elevating stress-hormone levels does not represent a natural stress response, and is therefore difficult to translate to human conditions. Moreover, the administration of CORT (drinking water, pellets, injections), its form (corticosterone or corticosterone 21-hemisuccinate) and the dosage, plays an important role, and slight changes in these factors may elicit different responses. The highest densities of glucocorticoid receptors are found in the hippocampus, frontal cortex, and the amygdala, structures involved in cognitive function [133], as well as regulation of the stress axis [134]. While the hippocampus is believed to mediate spatial memory [135], the prefrontal cortex is involved in executive function, such as goal-directed behavior or attention. Interestingly, in the literature of animal research, adolescent CORT administration mainly affects hippocampal morphology, but does not appear to elicit any behavioral phenotype. One particular study showed that while chronic adolescent stress induced by restraint stress ( $6 \mathrm{~h}$ daily for 3 weeks) impaired spatial short-term memory, no such effect was seen after CORT administration in drinking water $(40 \mathrm{mg} / \mathrm{L})$ during the same period; however, both stressors reduced dendrite arborization in the hippocampus [53]. This highlights a more profound effect of chronic restraint stress during adolescence on cognitive function, as compared to CORT treatment alone, and suggests involvement of other stress hormones, such as adrenaline. In line with this study, our own data did not show any deficits in spatial short-term memory in rats after administering CORT in drinking water $(50 \mathrm{mg} / \mathrm{L})$ for 3 weeks $(8-10$ weeks of age), albeit that rats were given a two-week gap between the end of CORT treatment and behavioral testing [46]. In another study by our group, after administering CORT (50 mg/L) from week 6-9 in mice, we uncovered a male-specific disruption to sensorimotor gating as measured by pre-pulse inhibition (PPI) [59]. Disruptions in sensorimotor gating are frequently reported in schizophrenia patients [136]. Our study suggests that males are more susceptible to develop PPI deficits when exposed to high stress-hormone levels during adolescence as compared to females.

Overall, CORT treatment during adolescence appears to have either no effects or induce subtle molecular changes that do not transpire to behavioral abnormalities, but may be a triggering event when combined with an additional environmental or genetic insult $[46,59,137,138]$. For instance, we found that male, but not female mice that are heterozygous for the BDNF gene, when given adolescent CORT treatment, developed short-term spatial memory deficits in adulthood, as shown by the Y-maze [137]. Furthermore, sex-specific deficits were also uncovered when mice that were exposed to maternal separation (PND 2-14, $3 \mathrm{~h}$ /day) were given CORT treatment during young adulthood [138]. This "two-hit" paradigm resulted in a male-specific deficit in short-term spatial memory as shown by the Y-maze. Interestingly, females exposed to the "two-hit" treatment displayed anhedonia phenotype in the sucrose-preference test. These behavioral phenotypes were matched with reductions in mBDNF protein level, specifically in the dorsal hippocampus in the male two-hit mice, while mBDNF level was specifically reduced in the ventral hippocampus in the female two-hit mice. These lines of evidence suggest that increased stress hormone during the adolescent phase can induce a vulnerability seeded by earlier stress experiences and result in sex-specific pathologies. While males appear to develop memory deficits when exposed to adolescent CORT treatment as a second hit, females tend to develop depression-like behavior.

Adolescence is one of the most dynamic periods of brain and body development, second only to infancy. However, unlike infancy, an adolescent is much more exposed to the myriad of stressors. The available evidence suggest that this period is acutely sensitive to stress-induced changes that can pervade into adulthood. Given sexual maturation occurs during this time, it is unsurprising that sexually distinct patterns of stress adaptation also occur, leading to different outcomes in response to stress. A better understanding of the mechanisms underlying the interplay of environment, genetic, 
and developmental factors during this crux phase may offer novel opportunities to prevent or treat stress-related disorders. In terms of face validity of the above-described models of adolescent stress, we observed that the majority of studies investigating the effect of adolescent stress focus on behavioral paradigms relevant to mental illnesses, rather than cognitive function, per se $[57,139,140]$. Similarly, human studies examining the effect of adolescent stress tend also to focus on mental illness rather than cognition [141]. Irrespectively, those studies focusing on cognition in humans tend to show cognitive abnormalities in tasks that are mainly mediated by the PFC [90], whereas the majority of rodent studies focus on the hippocampus-dependent memories, such as spatial short-term or long-term memories, as described above. Hence, the face validity of adolescent stress paradigms has to be strengthened by an increased focus on PFC-related tasks in animal models, such as, for example, the 5-choice serial reaction time task, using touch-screen apparatus, to assess similar types of PFC-dependent cognitive function, which is seen to be affected in humans.

\section{Adult Stress Models}

The association between severe or prolonged stress and subsequent development of psychiatric disorders is encapsulated by acute stress disorder (ASD) and post-traumatic stress disorder (PTSD), the diagnoses of which are both dependent on the experience of a traumatic event. However, a plethora of psychiatric disorders, such as depression and anxiety, are also intimately linked with stressful experiences, not only during developmental stages, but also during adulthood. Despite the well-established observation that PTSD as well as depression are more common in women compared to men [14-16], once again, not many studies have examined sex differences within this context.

\subsection{Physical and Social Stress in Adulthood}

With regards to physical stress, Crema and colleagues [61] showed that chronic restraint stress, 5 days a week for 40 days starting at PD 60, resulted in anxiety-like behavior in male Wistar rats. In male mice, a similar paradigm of $2 \mathrm{~h}$ of restraint stress a day for 21 days, starting at PD 38 as well as physical CUS, resulted in body weight loss and a depression-like phenotype measured via the tail-suspension test [63]. Other versions of chronic restraint stress have subjected rats to a daily session of $12 \mathrm{~h}$ duration for 2 days, which suppressed immunity by inducing lymphocyte apoptosis [62]. Interestingly, this echoes clinical findings where, following traumatic stress in humans, there is a reduced immune response [142]. Chronic immobilization stress for $2 \mathrm{~h}$ a day over 21 days in 2-month-old male rats resulted in a deficit in recall memory in the Morris water maze [64]. Adult male Lister rats exposed to a variety of physical stressors (physical CUS) over 5-9 weeks developed an anhedonic phenotype, as measured by the sucrose preference test [65]. A similar 4 week paradigm also resulted in anhedonic behavior, and increased submissive behavior in the residential intruder test, but an anxiolytic phenotype in the elevated-plus maze [66]. Even a relatively short 10-day paradigm was enough to elicit anxiety-like behavior in male rats, as shown in the defensive burying test, despite no alterations in the phenotypes in the elevated plus maze and the light/dark box [67]. In 10-week-old male mice, a 54-day paradigm of twice-a-day exposure to various stressors, including physical and social stressors, resulted in depressive-like, anxiety, and submissive phenotypes [60]. Another study compared 4 weeks of physical CUS (such as restraint in a plastic tube, cage tilting, placement in an empty cage with no nesting, placement in crowded cages, lights on for a short period of time during the dark phase, and white noise) and chronic restraint stress of the same duration in adult mice, and found that whilst both regimes produced anxiety phenotypes, only the CUS was able to elicit depressive-like behaviors [68]. It should be noted that strain differences exist as shown by a 3-week protocol which resulted in different phenotypes in two strains of inbred mice, with the C57BL/ 6 but not ICR mice developing a depression-related phenotype [143]. The majority of the abovementioned studies mainly report depression-like and anxiety-like phenotype in response to physical stress, and CUS appears to have a more profound effect on depression-like behavior compared to a single chronic stressor. 
Not many studies reported cognitive impairment after adult physical stress except one, which showed a deficit in recall memory after 21 days of immobilization stress in male rats [64].

In terms of social stress, in male rats, social defeat stress (introducing an intruder into the cage) induced depression-like behavioral phenotypes, impaired memory, and increased oxidative stress and inflammation [72]. In agreement with this study, Martin et al. [73] showed that chronic defeat stress for 10 consecutive days starting at PD 48 induced long-lasting anxious-like phenotype in the open field and episodic memory deficits in the novel object recognition test in male C57BL/6J mice. Another study showed that social defeat stress for 21 days in adult mice resulted in disrupted spatial memory accompanied by reduced complexity of apical dendrites of CA3 neurons [74]. Interestingly, a study has found that social defeat in patients predicted diagnosis of PTSD and course of disease remission [144]. Taken together, while the majority of the studies using physical stressors report depression-like or anxiety-like behavior in rodents, social stress appears to affect hippocampus-dependent cognitive function as well as induce depression-like behavior.

Exposure of rodents to cat urine, ferret urine, or trimethylthiazoline (TMT), a synthetic compound distilled from fox feces, can elicit various stress responses such as freezing, avoidance, and increases in stress hormones $[145,146]$. Areas such as the paraventricular nucleus of the hypothalamus (PVN), medial amygdala (MeA), and dorsal periaqueductal gray (PDAG) are intimately involved in the response to chemosignals, inducing autonomic, endocrine, and behavioral responses [147,148]. Predator exposure has been found to elicit long-lasting anxiogenic behavioral [149] and pathological neuroadaptations in the expression of synaptophysin and cannabinoid systems, both of which are involved in PTSD [150,151]. A recent study found that exposure to TMT induced impairments in memory retrieval in the radial arm maze in male mice [152].

Disruptions to the normal circadian rhythm can upset both the physical and psychological wellbeing of an individual [153]. Likewise, in mice, it has been shown that exposure to constant light for three weeks caused depressive-like and anxiety-like behaviors but decreased CORT [75]. Other studies found no changes in memory or anxiety parameters after 3-4 weeks of constant light exposure [77]. Craig and colleagues used, in Long Evans rats, a chronic phase shifting protocol. Light-off time was brought forward for $3 \mathrm{~h}$ each day for 6 days before 10 days of re-entrainment light-off at 22:30. This 16-day protocol was considered one session. Rats exposed to 4 consecutive sessions (at PD 64) developed hippocampal memory deficits in the Morris water maze test [78]. In the diurnal Nile grass rat, introduction of light in the dark phase for 3 weeks induced a range of phenotypes, including anhedonia, as shown by the sucrose preference test, increased immobility in the forced-swim test (FST), and impaired learning and memory in the Barnes maze. Concurrently, night time light reduced dendritic length in the DG and CA1 [76]. Adaptation by the animals to the change in day-night pattern is a major drawback, as no long-term study can be conducted. For this reason, most studies use this as a part of an unpredictable stress paradigm. Interestingly, changes in circadian rhythm seem to have a profound effect on depression-like behavior, as well as memory performance, as shown by several studies, which were also reported after social defeat stress.

While the aforementioned data is based on male rodents only, more recent studies began to focus on differential response to stressors in males and females. Viera et al. [69] recently compared the effects of repeated restraint stress over 10 days versus chronic variable stress over 10 days on 60-day-old (adult) male and female rats. This study showed that irrespective of stress type males were more vulnerable to somatic effects of chronic stressors, while females appeared to be more susceptible to neuroendocrine and behavioral changes, and developed anxiety-like behavior. Indeed, depression, as well as PTSD, have a higher prevalence in females [14-16], and may result from a differential response to stress in males and females. Bowman and colleagues [70] investigated the impact of the duration of restraint stress on short-term spatial memory performance in female rats. Twenty-one days ( $6 \mathrm{~h}$ per day) of chronic restraint stress at PD 70 enhanced female 8-arm radial arm maze (RAM) performance (spatial memory) in female rats, while 28 days neither enhanced nor impaired performance [70]. This pattern of results is different from male rats, in which prolonged exposure to stress changes from enhanced 
spatial memory at 14 days of adult stress to maladaptive (RAM performance was impaired following 21 days of restraint) [71]. These results are consistent with the data from male studies as outlined at the beginning of the section, showing that physical stress during adulthood for longer than three weeks has maladaptive effects.

\subsection{Pharmacological Stress in Adulthood}

Administration of glucocorticoid in rodents has been found to reduce hippocampal neurogenesis $[31,32,80]$, increase apoptosis $[33,81,83,84,154]$, and reduce volume and dendritic density of the prefrontal cortex $[34,155]$. Behaviorally, chronic oral CORT administration $(100 \mathrm{ug} / \mathrm{mL})$ to adult mice resulted in depressive-like behavior in the FST [79]. In rats, chronic injection of the more modest $20 \mathrm{mg} / \mathrm{kg}$ dose of CORT elicited depressive-like behavior in the FST, decreased body weight and, in a subset of high anxiety rats, increased anxiety-like behavior in the open field and elevated plus maze test [82]. However, the relationship between levels of circulating glucocorticoids and pathological outcomes is complex. For example, lower baseline cortisol levels have been found in patients suffering PTSD as a result of acute respiratory disease syndrome [156]. In another study, low dose cortisol (10 mg/day) was administered daily for 1 month to three patients with chronic PTSD and resulted in significant improvements [157]. An acute intravenous injection of a high dose of hydrocortisone $(100-140 \mathrm{mg})$ to patients with acute stress symptoms within the first $6 \mathrm{~h}$ of a traumatic event was able to attenuate symptoms of the acute stress, as well as the subsequent PTSD in the 25 patients [158].

Similar findings have been reported in rodents [159]. This seemingly inconsistent effect may be due to the memory mediating effect of glucocorticoids-initial increases in glucocorticoid levels in response to stress can act to obstruct long-term memory formation of the traumatic event [160]. Hence, the use of exogenous glucocorticoid alone in stable dosages may only represent a single dimensional aspect of stress - that is, the effects of elevated glucocorticoid-and may miss the dynamic flux of the organism as it attempts to regain (or fail to, in pathological cases) homeostasis. It is also important to keep in mind not only the difference between the species (mice, rats), but also between strains, have to be taken into account when interpreting the effects of CORT. Chronic CORT administration (pellets of $20 \mathrm{mg}$ CORT) to C56BL/ 6 mouse substrains J and $\mathrm{N}$ at 12 weeks of age for 3 weeks showed differential behavioral and molecular responses [85]. While C56BL/6N mice developed depression-like behavior, C56BL/6J mice remained resistant to adolescent CORT exposure [85]. While many studies purely focus on male mice, Mekiri and colleagues [86] used only female C57BL/6J mice to investigate the effect of chronic CORT administration to model an anxio-depression-like phenotype. They showed that 4 weeks of CORT exposure at $35 \mathrm{~g} / \mathrm{L}$ in the drinking water enhanced the emotionality score of female mice, but with a very small effect size. Tests of longer treatment duration, however, failed to potentiate the behavioral effects of CORT. CORT had no effect on cell proliferation, survival, or neuronal maturation in the dentate gyrus of the hippocampus in this female model, suggesting other stress mechanisms play a more profound role in anxiety-like behavior, rather than stress-hormone levels, per se, in females. Taken together, although inconsistencies exist between studies, the majority of the literature report that chronic CORT administration during adulthood induces depression-like and anxiety-like behavior, decreased neurogenesis, and dendritic arborization (mainly in cortex and hippocampus) in male rodents. Female rodents, on the other hand, appear to be protected against high CORT levels during adulthood, and did not show any molecular differences, and even exhibited greater emotionality scores after four weeks of CORT exposure. The available evidence strongly advocates for the need to include both male and female animals in modelling stress-induced pathologies.

\section{Genetically Modified Animal Models and the Study of Stress}

Recent advances in mouse genetics within the past two decades has allowed for the generation of multiple mouse lines of relevance to the study of stress. The HPA axis is comprised of many regulatory elements, which, when disrupted, may result in abnormal stress reactivity. Examples include a polymorphism (5-HTTLPR) within the promoter region of the serotonin transporter gene, 
where a short allele, with a 43 bp deletion, results in hypersensitivity of the HPA axis [161-163]. Another example is the single nucleotide polymorphism (rs53576) in the oxytocin receptor gene, which has been shown to modulate HPA-axis stress responses [164]. However, there is commonality in their function to control circulating stress-steroid hormones from acting on their principal binding sites-the glucocorticoid (GR) and mineralocorticoid (MR) receptors $[165,166]$. Therefore, the study of GR and MR signaling reflects two of the most downstream events involved in the behavioral adaptation to stress. Early pharmacological studies implicated GR and MR receptor function in many behavioral processes, highlighting their functional significance. However, as previously noted, these studies lacked temporal, regional, or cell-type specificity for either receptor, which affected the overall utility of these models [167]. Given the generation of at least eight distinct GR and three MR mutant mouse lines [168], which vary in their genetic construct to overexpress, underexpress, knock-out (KO), and determine mechanisms of signaling, these receptor systems represent model systems to outline how various genetic manipulations can be used to deduce the mechanisms and pathways involved in the behavioral response to stress. In this section, these genetically modified GR and MR animal models will be briefly discussed where phenotyped, to outline how genetically modified animal models may be used to further tease out the mechanisms involved in behavioral adaption to stress.

\subsection{Early Insight from Non-Specific Loss- and Gain-of-Function Models}

Countering claims that pharmacological models were too non-specific [167], the generation of GR and MR KO mice presented a leap forward in receptor specificity. However, $\mathrm{GR}^{-/-}$and $\mathrm{MR}^{-/-} \mathrm{KO}$ mice often die within hours or days following birth by means of respiratory failure [169] and renal $\mathrm{Na}^{+}$loss [170], respectively. It is possible to extend the lifespan of $\mathrm{MR}^{-/-} \mathrm{KO}$ mice by administration of exogenous $\mathrm{NaCl}$; a strategy that has been used to implicate a putative role of MRs, and not GRs, in maintaining granule cell neurogenesis within the hippocampus of adult mice [171]. However, while exogenous salt treatment may extend the lifespan of $\mathrm{MR}^{-/-} \mathrm{KO}$ mice into adulthood [171,172], neither $\mathrm{MR}^{-/-}$nor $\mathrm{MR}^{-/+}$mice appear to have been extensively behaviorally phenotyped to date, and it remains unclear whether MR-mediated granule cell neurogenesis within the hippocampus of salt-treated $\mathrm{MR}^{-/-} \mathrm{KO}$ mice alters behavioral output. Further, despite reports that $10 \%$ of $\mathrm{GR}^{-/-}$ mice survive to adulthood [173], only $\mathrm{GR}^{+/-}$mice have been behaviorally phenotyped; presumably because it is unknown if the severity of other developmental anomalies [169] may otherwise affect behavior. Speculation aside, GR heterozygote mice have been shown to have normal CORT levels at baseline, but show extended CORT elevations 40 and $60 \mathrm{~min}$ following restraint stress, while an exaggerated CORT response was also observed following challenge with dexamethasone (DEX) and DEX + CRF [174]. Behaviorally, no evidence of anxiety-related behavior (as evaluated using the elevated O-maze, light-dark box, and fear conditioning) was observed amongst $\mathrm{GR}^{+/-}$mice in this study, however, on a shuttle-box test of learned helplessness, $\mathrm{GR}^{+/-}$mice were shown to have increased escape latencies and failures suggesting a depressive-like phenotype; a finding which coincided with decreased BDNF protein expression within the hippocampus of $\mathrm{GR}^{+/-}$mice [174]. Interestingly, within this same study, the authors also behaviorally phenotyped a GR overexpressing transgenic mouse line that had been genetically modified to carry two extra copies of the GR gene by means of a yeast artificial chromosome [175], allowing for the direct comparison of the behavioral effects of GR downand upregulation. These mice, termed $\mathrm{GR}^{\mathrm{YGR}}$ transgenic mice, were shown to have a phenotype opposite to that of $\mathrm{GR}^{+/-}$mice, by showing decreases in HPA-axis reactivity following restraint stress and challenge with DEX, a resilient phenotype on the shuttle-box learned-helplessness paradigm, and an increase in hippocampal BDNF relative to controls [174]. It is worth noting, however, that the expression levels of $\mathrm{GR}^{+/-}$and $\mathrm{GR}^{\mathrm{YGR}}$ mice are not proportionate. In this study, GR heterozygote mice showed a downregulation of GR mRNA to $33 \%$ of littermate controls, while GR ${ }^{\mathrm{YGR}}$ mice showed upregulation of GR mRNA to $219 \%$ of littermate controls [174], which suggests that, based on the relative difference in gene expression between the two models, disruptions to GR gene expression has the ability to shape behavioral processes. Lastly, an alternative loss of function model, where 
animals carry an inverted antisense GR cDNA allele under the control of a putatively neuronal-specific neurofilament promoter [176,177], also showed evidence of a resilient phenotype by showing reduced immobility and an increased latency to first immobility on the FST [176]. That said, unlike $\mathrm{GR}^{+/-}$ mice, these antisense GR (AGR) mice showed a significant increase on number of arm entries and time exploring the open arm on the elevated plus-maze, and a selective deficit on a social-recognition paradigm compared to controls, which were normalized by the antidepressant moclobemide [176]. Despite trying to control expression of GR specifically within the brain, these AGR mice also reportedly suffer from alterations in GR expression within peripheral tissue [168], making it less specific than the more modern, and regionally-specific, conditional knockout strains.

\subsection{Insight from Brain-Specific and Forebrain-Restricted Depletion of GR and MR}

The first study to generate conditional Cre/LoxP GR KO mice, using nestin (Nes) to direct deletion of GR within the nervous system, reported dysregulated basal CORT levels, reduced ACTH levels, and overexpression of CRF within the PVN [178]. Promisingly, these $\mathrm{GR}^{\mathrm{Nes} C r e}$ mice show no major morphological anomalies within the adrenal glands, which are otherwise severely affected in $\mathrm{GR}^{-1-}$ KO mice [169], but do show evidence of adrenal sensitivity on ACTH stimulation tests [178]. The behavioral phenotype of these $\mathrm{GR}^{\mathrm{Nes} C \mathrm{re}}$ mice was associated with an anxiolytic-like phenotype, whereby mutant mice showed a reduced latency to enter the "light" environment, and spent more time exploring it, on the light-dark box test, which was complemented by longer exploration times of the open section of the elevated zero-maze relative to controls [178]. Further to this, GR ${ }^{\text {NesCre }}$ mice also showed a resilient phenotype on the forced-swim test (FST), where there was no significant difference in immobility compared to controls on day one of testing, but when repeated on day two, $\mathrm{GR}^{\mathrm{Nes} C r e}$ mice swam for significantly longer than controls. While this test has been classically used as a measure of learned helplessness, of relevance to affective disorders, it has also been suggested that this FST phenotype of GR ${ }^{\text {NesCre }}$ mice may represent a cognitive deficit whereby mutants are unable to learn that attempts to escape are futile [168]. In a separate study, and of relevance to addiction, $\mathrm{GR}^{\mathrm{Nes} C r e}$ mice were shown to have a "flattened" dose-response function to, but showed intact acquisition of, intravenous cocaine self-administration, while behavioral sensitization to cocaine was completely suppressed [179]. Molecularly, $\mathrm{GR}^{\mathrm{Nes} C r e}$ mice show downregulated expression of synapsin isoforms Ia/Ib, but not IIa or IIIa, and the transcription factor Egr-1 within the hippocampus [180]. Linking this to behavioral function, wildtype mice, which undergo contextual fear conditioning followed by intra-hippocampal infusion of CORT, selectively show upregulated synapsin-Ia/Ib expression and enhanced contextual fear, which suggests a putative signaling pathway, comprising GR-Egr1-MAPK-Syn-Ia/IB, related to the processing of stress-related memory $[180,181]$. Based on this result, it would be of interest to examine whether this same signaling pathway within $\mathrm{GR}^{\mathrm{Nes} C r e}$ mice plays a role in the renewal of contextual fear following extinction learning, and may be an avenue of further research.

A step-up in specificity, forebrain-specific ablation of GR and MR signaling has implicated the role of these receptors in limbic function. Mice with a forebrain-specific deletion of GRs, which were also developed using the Cre/LoxP system, are termed GR ${ }^{\mathrm{CaMKCre}}$ for being under the control of calmodulin kinase, and show evidence of HPA-axis hyperactivity, increased behavioral despair, and depressive-like behavior on the sucrose preference test, FST, and tail-suspension test (TST) [182]. While treatment with the antidepressant imipramine reversed the FST and TST phenotype [182], a separate study assessing both males and females replicated the depressive-like phenotype of male $\mathrm{GR}^{\mathrm{CaMKCre}}$ mice, but failed to find evidence of HPA-axis hyperactivity nor depressive-like behavior amongst female GR ${ }^{\text {CaMKCre }}$ mice [183]. Similarly, when crossed onto a new foundation line with a pure C57BL/ 6 background, the deletion of forebrain GRs once more failed to induce this male-specific phenotype [184]. While these results highlight sex differences and the fact that antidepressant treatment appears to act independently of forebrain GR expression, these contradictory behavioral results suggest the need for further study before these data can be extrapolated to clinical cases. On the other hand, 
$\mathrm{MR}^{\mathrm{CaMKCre}}$ mice also show no disruption in basal nor stress-induced HPA-axis reactivity relative to controls, and show no evidence of an anxiety-related phenotype on the open field, elevated O-maze, and light-dark box tests [185]. That said, deficits in the acquisition and reversal phases of the Morris water maze, specifically during the early phase of testing, were observed amongst $\mathrm{MR}^{\mathrm{CaMKCre}}$ mice, while on the radial arm maze, the working memory of $\mathrm{MR}^{\mathrm{CaMKCre}}$ mice was also selectively disrupted. Within the hippocampus, $\mathrm{MR}^{\mathrm{CaMKCre}}$ mice showed altered mossy fiber projections and significantly increased GR expression within the Cornu Ammonis (CA) field [185]. A more recent study also found that $\mathrm{MR}^{\mathrm{CaMKCre}}$ mice also showed delayed learning on the circular hole board (CHB) test, and while 5-10 min of acute restraint stress disrupted task learning amongst the control group, the MRCaMKCre mice remained unaffected; a result which suggests a role for MRs in the stress-induced formation of hippocampus-dependent spatial memory [186]. It is worth noting that this study utilized a male-only sample. In a separate study by the same group, only female $\mathrm{MR}^{\mathrm{CaMKC}} \mathrm{re}$ mice were sampled, and a similar CHB deficit was observed, but only when mice were in proestrus and estrus. Further to this, stress-susceptibility on CHB performance was also observed but was once more specific to MRCaMKCre female mice in estrus [187]. Cumulatively, these studies show a selective role for MRs in the early formation of spatial memory traces, and that stress-susceptibility may be dependent on other endocrine systems, highlighting the need to include sex as a factor in the investigation of complex interactions in the behavioral modelling of stress.

\subsection{Insight from Deficient DNA Binding in $G R^{\text {Dim }}$ Mice}

As GRs exert their action by DNA binding both directly, via glucocorticoid response elements (GRE), and indirectly, via interactions with transcription factors, the behavioral dissection of these two pathways is, therefore, a necessary but challenging task. One model, however, involving the insertion of a point mutation termed A458T within the D loop, a region of 5 amino acids within the DNA-binding domain of GR located in exon 4 [188], which affects dimerization, DNA binding, and subsequently, the transactivation of GRE-containing promoters [189]. Mice carrying this genetic variant, termed GR dimerization-deficient or $\mathrm{GR}^{\mathrm{Dim}}$ mice [188], are therefore deficient in dimer-required DNA-mediated GR function, but not monomer-mediated protein-protein interactions with other transcription factors [190], allowing for pathway specificity when interrogating the behavioral effects of GR function. Correspondingly, GR ${ }^{\mathrm{Dim} / \mathrm{Dim}}$ mice have been shown to have unchanged CRF expression within the PVN and median eminence, suggesting that GR control of CRF may be dimer independent, while POMC expression was increased within the anterior pituitary [188]. ACTH immunoreactivity was increased 2.2-fold in the anterior pituitary as expected, however, serum ACTH was found to be unchanged, which the authors suggested could be the result of a dimerization-independent secretion mechanism. However, radioimmunoassay did reveal increased basal CORT levels [188], which remain elevated relative to controls following one minute of swim stress after 30 and $90 \mathrm{~min}$ [190]. Behaviorally, significantly longer swim distances and latencies to locate the platform than controls on the water-maze have been observed, suggesting impaired spatial memory, but unlike other models, no evidence of an anxiety-related phenotype on the light-dark box and open field test has been observed [190]. Given that the dorsal hippocampus is putatively a critical mediator of spatial memory [191], while the ventral hippocampus is believed to have a more prominent role in anxiety-related behavior [192], it is interesting to note that GR expression is approximately two-fold higher in the dorsal hippocampus relative to the ventral hippocampus in both rat and mouse $[193,194]$. In this regard, it is possible that in GR ${ }^{\mathrm{Dim} / \mathrm{Dim}}$ mice, the dorsal hippocampus is more severely affected by the disruption of GR dimerization and DNA-binding processes than the ventral hippocampus, resulting in memory impairment rather than an anxiety-related phenotype. Complementary to this interpretation, the behavioral phenotype of $\mathrm{GR}^{\mathrm{Dim} / \mathrm{Dim}}$ mice may also suggest that spatial memory deficits are under the control of GR dimerization, while anxiety-related behavior is mediated by GR monomer action [195], providing distinct regions and signaling pathways by which glucocorticoids 
may regulate behavioral and cognitive processes. It would be interesting to further evaluate whether there are sex-specific differences with regards to GR dimerization and DNA-binding processes.

\section{Conclusions}

Here, we compared and summarized the most recent evidence of rodent stress models used in research to better understand the mechanism underlying chronic stress. Due to an enormous amount of data in stress research, including numerous types of stress within different species and time points of stress application, we organized this review into three major time points of chronic stress application: (1) postnatal early life, (2) adolescence, and (3) adulthood. We further only focused on how this chronic stress affects mainly behavior, but also molecular composition in adulthood. For each section, we classified the type of stress into physical, social, and pharmacological stress to better distinguish and interpret the behavioral and molecular results.

Despite the mentioned variability and inconsistency between studies in terms of type/duration of stress, window of stress application, and type of test and timing of assessment, we could see major parallels of early, adolescent, and adult stress on behavioral outcome. Psychological stress during early postnatal life can have a long-lasting detrimental impact on cognitive function, but can also create resilience, particularly to fear-potentiated memory, depending on the exact stress paradigm and timing of the stressor. It may, indeed, explain the notion that early stress could in fact prepare the organism to function better under high stress later in life, when the individual possesses a certain predisposition to stress reactivity, dictated by early experience. Furthermore, with only a few sex-specific studies, males seem to be more susceptible to early life stress compared to females. No studies of stress application during adolescence showed any beneficial effects on behavior. These studies mainly report abnormal depression-like or cognitive behavior with molecular abnormalities mainly in the hippocampus or the prefrontal cortex. A few studies showed that physical stress has a higher impact on the stress response compared to social stress. Sex and brain specific abnormalities were reported after adolescent physical and social stress, with males tending to fare worse in terms of hippocampal-dependent memory outcomes. With regards to CORT application during adolescence, our own laboratory showed a male-specific disruption in sensory gating as measured by PPI, suggesting that CORT has a greater effect in males compared to females, and in a two-hit paradigm, maternal separation followed by adolescent CORT treatment caused spatial memory deficits in males, but anhedonia in females, showing sex-specific effects of adolescent CORT exposure. Interestingly, according to the studies on adolescent/adult pharmacological stress and GR receptor conditional $\mathrm{KO}$ mice, females were not affected or less affected than males in terms of developing a behavioral despair phenotype. This suggests that other stress mechanisms must be involved in females besides the glucocorticoid-GR signaling pathway, while males seem to be more affected by alterations to glucocorticoid signaling.

Notwithstanding the current valuable advances in stress research using animal models, investigators should be more mindful of which type of rodent, including strain, age and sex, which type of stressor, and what time points/duration of stress application/behavioral or molecular assessment to use in order to obtain results with high translational relevance echoing human disorders. Given significant sex differences in stress reactivity, both male and female rodents should be assessed in order to investigate sex-specific mechanisms underlying stress reactivity. This will not only shed more light on the underlying mechanisms of stress-related disorders, but will help to develop more targeted treatment options.

Author Contributions: Conceptualization, A.S., M.N., X.D. and R.A.H.; Funding acquisition, A.S., M.N., X.D. and R.A.H.; Supervision, R.A.H.; Writing—original draft, A.S., M.N. and X.D.; Writing-review \& editing, A.S., X.D. and R.A.H.

Funding: This research received no external funding. 
Acknowledgments: A.S. is in receipt of a Melbourne International Research Scholarship as well as a Melbourne International Fee Remission Scholarship. M.N. is supported by a National Health and Medical Research Council (NHMRC) of Australia early career fellowship. X.D. is supported by a NHMRC/ARC dementia fellowship. R.H. is supported by a NHMRC Career development fellowship.

Conflicts of Interest: The authors declare no conflict of interest.

\section{References}

1. Bao, A.M.; Meynen, G.; Swaab, D.F. The stress system in depression and neurodegeneration: Focus on the human hypothalamus. Brain Res. Rev. 2008, 57, 531-553. [CrossRef] [PubMed]

2. De Kloet, E.R.; de Jong, I.E.M.; Oitzi, M.S. Neuropharmacology of glucocorticoids: Focus on emotion, cognition and cocaine. Eur. J. Pharmacol. 2008, 585, 473-482. [CrossRef] [PubMed]

3. Macdonald, I.A.; Bennett, T.; Fellows, I.W. Catecholamines and the control of metabolism in man. Clin. Sci. 1985, 68, 613-619. [CrossRef] [PubMed]

4. Borodovitsyna, O.; Flamini, M.; Chandler, D. Noradrenergic modulation of cognition in health and disease. Neural Plast. 2017, 2017, 6031478. [CrossRef] [PubMed]

5. McGaughy, J.; Ross, R.S.; Eichenbaum, H. Noradrenergic, but not cholinergic, deafferentation of prefrontal cortex impairs attentional set-shifting. Neuroscience 2008, 153, 63-71. [CrossRef] [PubMed]

6. Alexander, J.K.; Hillier, A.; Smith, R.M.; Tivarus, M.E.; Beversdorf, D.Q. Beta-adrenergic modulation of cognitive flexibility during stress. J. Cogn. Neurosci. 2007, 19, 468-478. [CrossRef] [PubMed]

7. McCarty, R.; Horwatt, K.; Konarska, M. Chronic stress and sympathetic-adrenal medullary responsiveness. Soc. Sci. Med. 1988, 26, 333-341. [CrossRef]

8. Konarska, M.; Stewart, R.E.; McCarty, R. Sensitization of sympathetic-adrenal medullary responses to a novel stressor in chronically stressed laboratory rats. Physiol. Behav. 1989, 46, 129-135. [CrossRef]

9. Kvetnansky, R.; Pacak, K.; Fukuhara, K.; Viskupic, E.; Hiremagalur, B.; Nankova, B.; Goldstein, D.S.; Sabban, E.L.; Kopin, I.J. Sympathoadrenal system in stress. Interaction with the hypothalamic-pituitaryadrenocortical system. Ann. N. Y. Acad. Sci. 1995, 771, 131-158. [PubMed]

10. De Kloet, E.R.; Joels, M.; Holsboer, F. Stress and the brain: From adaptation to disease. Nat. Rev. Neurosci. 2005, 6, 463-475. [CrossRef] [PubMed]

11. Goel, N.; Workman, J.L.; Lee, T.T.; Innala, L.; Viau, V. Sex differences in the HPA axis. Compr. Physiol. 2014, 4, 1121-1155. [PubMed]

12. Seale, J.V.; Wood, S.A.; Atkinson, H.C.; Bate, E.; Lightman, S.L.; Ingram, C.D.; Jessop, D.S.; Harbuz, M.S. Gonadectomy reverses the sexually diergic patterns of circadian and stress-induced hypothalamic-pituitaryadrenal axis activity in male and female rats. J. Neuroendocrinol. 2004, 16, 516-524. [CrossRef] [PubMed]

13. Bowman, R.E.; Beck, K.D.; Luine, V.N. Chronic stress effects on memory: Sex differences in performance and monoaminergic activity. Horm. Behav. 2003, 43, 48-59. [CrossRef]

14. Bekker, M.H.J.; van Mens-Verhulst, J. Anxiety disorders: Sex differences in prevalence, degree, and background, but gender-neutral treatment. Gend. Med. 2007, 4, S178-S193. [CrossRef]

15. Breslau, N.; Davis, G.C.; Andreski, P.; Peterson, E.L.; Schultz, L.R. Sex differences in posttraumatic stress disorder. Arch. Gen. Psychiatry 1997, 54, 1044-1048. [CrossRef] [PubMed]

16. Tolin, D.F.; Foa, E.B. Sex differences in trauma and posttraumatic stress disorder: A quantitative review of 25 years of research. Psychol. Bull. 2006, 132, 959-992. [CrossRef] [PubMed]

17. Atkinson, H.C.; Waddell, B.J. Circadian variation in basal plasma corticosterone and adrenocorticotropin in the rat: Sexual dimorphism and changes across the estrous cycle. Endocrinology 1997, 138, 3842-3848. [CrossRef] [PubMed]

18. Bourke, C.H.; Harrell, C.S.; Neigh, G.N. Stress-induced sex differences: Adaptations mediated by the glucocorticoid receptor. Horm. Behav. 2012, 62, 210-218. [CrossRef] [PubMed]

19. Radley, J.J.; Rocher, A.B.; Miller, M.; Janssen, W.G.; Liston, C.; Hof, P.R.; McEwen, B.S.; Morrison, J.H. Repeated stress induces dendritic spine loss in the rat medial prefrontal cortex. Cereb. Cortex 2006, 16, 313-320. [CrossRef] [PubMed]

20. Michelsen, K.A.; van den Hove, D.L.; Schmitz, C.; Segers, O.; Prickaerts, J.; Steinbusch, H.W. Prenatal stress and subsequent exposure to chronic mild stress influence dendritic spine density and morphology in the rat medial prefrontal cortex. BMC Neurosci. 2007, 8, 107. [CrossRef] [PubMed] 
21. Magariños, A.M.A.; McEwen, B.S.; Flügge, G.; Fuchs, E. Chronic psychosocial stress causes apical dendritic atrophy of hippocampal CA3 pyramidal neurons in subordinate tree shrews. J. Neurosci. 1996, 16, 3534-3540. [CrossRef] [PubMed]

22. Mitra, R.; Jadhav, S.; McEwen, B.S.; Vyas, A.; Chattarji, S. Stress duration modulates the spatiotemporal patterns of spine formation in the basolateral amygdala. Proc. Natl. Acad. Sci. USA 2005, 102, 9371-9376. [CrossRef] [PubMed]

23. Bock, J.; Murmu, M.S.; Biala, Y.; Weinstock, M.; Braun, K. Prenatal stress and neonatal handling induce sex-specific changes in dendritic complexity and dendritic spine density in hippocampal subregions of prepubertal rats. Neuroscience 2011, 193, 34-43. [CrossRef] [PubMed]

24. Popoli, M.; Yan, Z.; McEwen, B.S.; Sanacora, G. The stressed synapse: The impact of stress and glucocorticoids on glutamate transmission. Nat. Rev. Neurosci. 2011, 13, 22-37. [CrossRef] [PubMed]

25. Scheggi, S.; Leggio, B.; Masi, F.; Grappi, S.; Gambarana, C.; Nanni, G.; Rauggi, R.; De Montis, M.G. Selective modifications in the nucleus accumbens of dopamine synaptic transmission in rats exposed to chronic stress. J. Neurochem. 2002, 83, 895-903. [CrossRef] [PubMed]

26. Marmigère, F.; Givalois, L.; Rage, F.; Arancibia, S.; Tapia-Arancibia, L. Rapid induction of bdnf expression in the hippocampus during immobilization stress challenge in adult rats. Hippocampus 2003, 13, 646-655. [CrossRef] [PubMed]

27. Smith, M.A.; Makino, S.; Kvetnansky, R.; Post, R.M. Stress and glucocorticoids affect the expression of brain-derived neurotrophic factor and neurotrophin-3 mRNAs in the hippocampus. J. Neurosci. 1995, 15, 1768-1777. [CrossRef] [PubMed]

28. Choy, K.H.C.; de Visser, Y.; Nichols, N.R.; van den Buuse, M. Combined neonatal stress and young-adult glucocorticoid stimulation in rats reduce bdnf expression in hippocampus: Effects on learning and memory. Hippocampus 2008, 18, 655-667. [CrossRef] [PubMed]

29. Murakami, S.; Imbe, H.; Morikawa, Y.; Kubo, C.; Senba, E. Chronic stress, as well as acute stress, reduces BDNF mRNA expression in the rat hippocampus but less robustly. Neurosci. Res. 2005, 53, 129-139. [CrossRef] [PubMed]

30. Duman, R.S.; Monteggia, L.M. A neurotrophic model for stress-related mood disorders. Biol. Psychiatry 2006, 59, 1116-1127. [CrossRef] [PubMed]

31. Brummelte, S.; Galea, L.A. Chronic high corticosterone reduces neurogenesis in the dentate gyrus of adult male and female rats. Neuroscience 2010, 168, 680-690. [CrossRef] [PubMed]

32. Cameron, H.A.; Gould, E. Adult neurogenesis is regulated by adrenal steroids in the dentate gyrus. Neuroscience 1994, 61, 203-209. [CrossRef]

33. Crochemore, C.; Lu, J.; Wu, Y.; Liposits, Z.; Sousa, N.; Holsboer, F.; Almeida, O.F. Direct targeting of hippocampal neurons for apoptosis by glucocorticoids is reversible by mineralocorticoid receptor activation. Mol. Psychiatry 2005, 10, 790-798. [CrossRef] [PubMed]

34. Cerqueira, J.J.; Pego, J.M.; Taipa, R.; Bessa, J.M.; Almeida, O.F.; Sousa, N. Morphological correlates of corticosteroid-induced changes in prefrontal cortex-dependent behaviors. J. Neurosci. 2005, 25, 7792-7800. [CrossRef] [PubMed]

35. Insel, T.; Cuthbert, B.; Garvey, M.; Heinssen, R.; Pine, D.S.; Quinn, K.; Sanislow, C.; Wang, P. Research domain criteria (RDoC): Toward a new classification framework for research on mental disorders. Am. J. Psychiatry 2010, 167, 748-751. [CrossRef] [PubMed]

36. Kessler, R.C.; Berglund, P.; Demler, O.; Jin, R.; Merikangas, K.R.; Walters, E.E. Lifetime prevalence and age-of-onset distributions of DSM-IV disorders in the national comorbidity survey replication. Arch. Gen. Psychiatry 2005, 62, 593-602. [CrossRef] [PubMed]

37. Costello, E.J.; Mustillo, S.; Erkanli, A.; Keeler, G.; Angold, A. Prevalence and development of psychiatric disorders in childhood and adolescence. Arch. Gen. Psychiatry 2003, 60, 837-844. [CrossRef] [PubMed]

38. Spear, L.P. The adolescent brain and age-related behavioral manifestations. Neurosci. Biobehav. Rev. 2000, 24, 417-463. [CrossRef]

39. Yuen, E.Y.; Wei, J.; Yan, Z. Molecular and epigenetic mechanisms for the complex effects of stress on synaptic physiology and cognitive functions. Int. J. Neuropsychopharmacol. 2017, 20, 948-955. [CrossRef] [PubMed]

40. Nasca, C.; Davis, E.; Bigio, B.; Sandi, C.; McEwen, B.S. Effects of Stress throughout the Lifespan on the Brain and Behavior; Academic Press Ltd-Elsevier Science Ltd.: London, UK, 2017; pp. 443-463. 
41. Aisa, B.; Tordera, R.; Lasheras, B.; Del Rio, J.; Ramirez, M.J. Cognitive impairment associated to HPA axis hyperactivity after maternal separation in rats. Psychoneuroendocrinology 2007, 32, 256-266. [CrossRef] [PubMed]

42. Oomen, C.A.; Soeters, H.; Audureau, N.; Vermunt, L.; van Hasselt, F.N.; Manders, E.M.M.; Joels, M.; Lucassen, P.J.; Krugers, H. Severe early life stress hampers spatial learning and neurogenesis, but improves hippocampal synaptic plasticity and emotional learning under high-stress conditions in adulthood. J. Neurosci. 2010, 30, 6635-6645. [CrossRef] [PubMed]

43. Champagne, D.L.; Bagot, R.C.; van Hasselt, F.; Ramakers, G.; Meaney, M.J.; de Kloet, E.R.; Joels, M.; Krugers, H. Maternal care and hippocampal plasticity: Evidence for experience-dependent structural plasticity, altered synaptic functioning, and differential responsiveness to glucocorticoids and stress. J. Neurosci. 2008, 28, 6037-6045. [CrossRef] [PubMed]

44. Suri, D.; Bhattacharya, A.; Vaidya, V.A. Early stress evokes temporally distinct consequences on the hippocampal transcriptome, anxiety and cognitive behaviour. Int. J. Neuropsychopharmacol. 2014, 17, 289-301. [CrossRef] [PubMed]

45. Liu, H.S.; Patki, G.; Salvi, A.; Kelly, M.; Salim, S. Behavioral effects of early life maternal trauma witness in rats. Prog. Neuro-Psychopharmacol. Biol. Psychiatry 2018, 81, 80-87. [CrossRef] [PubMed]

46. Hill, R.A.; Klug, M.; Von Soly, S.K.; Binder, M.D.; Hannan, A.J.; van den Buuse, M. Sex-specific disruptions in spatial memory and anhedonia in a "two hit" rat model correspond with alterations in hippocampal brain-derived neurotrophic factor expression and signaling. Hippocampus 2014, 24, 1197-1211. [CrossRef] [PubMed]

47. Lancaster, F.E. Sex differences in voluntary drinking by Long Evans rats following early stress. Alcoholism 1998, 22, 830-836. [CrossRef] [PubMed]

48. Chaby, L.E.; Sheriff, M.J.; Hirrlinger, A.M.; Lim, J.; Fetherston, T.B.; Braithwaite, V.A. Does chronic unpredictable stress during adolescence affect spatial cognition in adulthood? PLoS ONE 2015, 10, e0141908. [CrossRef] [PubMed]

49. Pyter, L.M.; Kelly, S.D.; Harrell, C.S.; Neigh, G.N. Sex differences in the effects of adolescent stress on adult brain inflammatory markers in rats. Brain Behav. Immun. 2013, 30, 88-94. [CrossRef] [PubMed]

50. Isgor, C.; Kabbaj, M.; Akil, H.; Watson, S.J. Delayed effects of chronic variable stress during peripubertal-juvenile period on hippocampal morphology and on cognitive and stress axis functions in rats. Hippocampus 2004, 14, 636-648. [CrossRef] [PubMed]

51. Hollis, F.; Isgor, C.; Kabbaj, M. The consequnces of adolescent chronic unpredictable stress exposure on brain behavior. Neuroscience 2013, 249, 232-241. [CrossRef] [PubMed]

52. Oztan, O.; Aydin, C.; Isgor, C. Chronic variable physical stress during the peripubertal-juvenile period causes differential depressive and anxiogenic effects in the novelty-seeking phenotype: Functional implications for hippocampal and amygdalar brain-derived neurotrophic factor and the mossy fibre plasticity. Neuroscience 2011, 192, 334-344. [PubMed]

53. Conrad, C.D.; McLaughlin, K.J.; Harman, J.S.; Foltz, C.; Wieczorek, L.; Lightner, E.; Wright, R.L. Chronic glucocorticoids increase hippocampal vulnerability to neurotoxicity under conditions that produce CA3 dendritic retraction but fail to impair spatial recognition memory. J. Neurosci. 2007, 27, 8278-8285. [CrossRef] [PubMed]

54. Caruso, M.J.; Crowley, N.A.; Reiss, D.E.; Caulfield, J.I.; Luscher, B.; Cavigelli, S.A.; Kamens, H.M. Adolescent social stress increases anxiety-like behavior and alters synaptic transmission, without influencing nicotine responses, in a sex-dependent manner. Neuroscience 2018, 373, 182-198. [CrossRef] [PubMed]

55. Sterlemann, V.; Rammes, G.; Wolf, M.; Liebl, C.; Ganea, K.; Muller, M.B.; Schmidt, M.V. Chronic social stress during adolescence induces cognitive impairment in aged mice. Hippocampus 2010, 20, 540-549. [CrossRef] [PubMed]

56. McCormick, C.M.; Thomas, C.M.; Sheridan, C.S.; Nixon, F.; Flynn, J.A.; Mathews, I.Z. Social instability stress in adolescent male rats alters hippocampal neurogenesis and produces deficits in spatial location memory in adulthood. Hippocampus 2012, 22, 1300-1312. [CrossRef] [PubMed]

57. McCormick, C.M.; Mathews, I.Z.; Thomas, C.; Waters, P. Investigations of HPA function and the enduring consequences of stressors in adolescence in animal models. Brain Cogn. 2010, 72, 73-85. [CrossRef] [PubMed] 
58. Morrissey, M.D.; Mathews, I.Z.; McCormick, C.M. Enduring deficits in contextual and auditory fear conditioning after adolescent, not adult, social instability stress in male rats. Neurobiol. Learn. Mem. 2011, 95, 46-56. [CrossRef] [PubMed]

59. Schroeder, A.; Bureta, L.; Hill, R.A.; van den Buuse, M. Gene-environment interaction of reelin and stress in cognitive behaviours in mice: Implications for schizophrenia. Behav. Brain Res. 2015, 287, 304-314. [CrossRef] [PubMed]

60. Tannenbaum, B.; Tannenbaum, G.S.; Sudom, K.; Anisman, H. Neurochemical and behavioral alterations elicited by a chronic intermittent stressor regimen: Implications for allostatic load. Brain Res. 2002, 953, 82-92. [CrossRef]

61. Crema, L.; Schlabitz, M.; Tagliari, B.; Cunha, A.; Simao, F.; Krolow, R.; Pettenuzzo, L.; Salbego, C.; Vendite, D.; Wyse, A.T.; et al. $\mathrm{Na}^{+}, \mathrm{K}^{+}$ATPase activity is reduced in amygdala of rats with chronic stress-induced anxiety-like behavior. Neurochem. Res. 2010, 35, 1787-1795. [CrossRef] [PubMed]

62. Yin, D.; Tuthill, D.; Mufson, R.A.; Shi, Y. Chronic restraint stress promotes lymphocyte apoptosis by modulating CD95 expression. J. Exp. Med. 2000, 191, 1423-1428. [CrossRef] [PubMed]

63. Yoon, S.H.; Kim, B.H.; Ye, S.K.; Kim, M.H. Chronic non-social stress affects depressive behaviors but not anxiety in mice. Korean J. Physiol. Pharmacol. 2014, 18, 263-268. [CrossRef] [PubMed]

64. Trofimiuk, E.; Walesiuk, A.; Braszko, J.J. St John's wort (hypericum perforatum) diminishes cognitive impairment caused by the chronic restraint stress in rats. Pharmacol. Res. 2005, 51, 239-246. [CrossRef] [PubMed]

65. Willner, P.; Towell, A.; Sampson, D.; Sophokleous, S.; Muscat, R. Reduction of sucrose preference by chronic unpredictable mild stress, and its restoration by a tricyclic antidepressant. Psychopharmacology 1987, 93, 358-364. [CrossRef] [PubMed]

66. D'Aquila, P.S.; Brain, P.; Willner, P. Effects of chronic mild stress on performance in behavioural tests relevant to anxiety and depression. Physiol. Behav. 1994, 56, 861-867. [CrossRef]

67. Matuszewich, L.; Karney, J.J.; Carter, S.R.; Janasik, S.P.; O’Brien, J.L.; Friedman, R.D. The delayed effects of chronic unpredictable stress on anxiety measures. Physiol. Behav. 2007, 90, 674-681. [CrossRef] [PubMed]

68. Zhu, S.; Shi, R.; Wang, J.; Wang, J.F.; Li, X.M. Unpredictable chronic mild stress not chronic restraint stress induces depressive behaviours in mice. Neuroreport 2014, 25, 1151-1155. [CrossRef] [PubMed]

69. Vieira, J.O.; Duarte, J.O.; Costa-Ferreira, W.; Morais-Silva, G.; Marin, M.T.; Crestani, C.C. Sex differences in cardiovascular, neuroendocrine and behavioral changes evoked by chronic stressors in rats. Prog. Neuro-Psychopharmacol. Biol. Psychiatry 2018, 81, 426-437. [CrossRef] [PubMed]

70. Bowman, R.E.; Zrull, M.C.; Luine, V.N. Chronic restraint stress enhances radial arm maze performance in female rats. Brain Res. 2001, 904, 279-289. [CrossRef]

71. Luine, V.; Villegas, M.; Martinez, C.; McEwen, B.S. Repeated stress causes reversible impairments of spatial memory performance. Brain Res. 1994, 639, 167-170. [CrossRef]

72. Patki, G.; Solanki, N.; Atrooz, F.; Allam, F.; Salim, S. Depression, anxiety-like behavior and memory impairment are associated with increased oxidative stress and inflammation in a rat model of social stress. Brain Res. 2013, 1539, 73-86. [CrossRef] [PubMed]

73. Martin, V.; Allaili, N.; Euvrard, M.; Marday, T.; Riffaud, A.; Franc, B.; Mocaer, E.; Gabriel, C.; Fossati, P.; Lehericy, S.; et al. Effect of agomelatine on memory deficits and hippocampal gene expression induced by chronic social defeat stress in mice. Sci. Rep. 2017, 7, 45907. [CrossRef] [PubMed]

74. Wang, X.D.; Chen, Y.C.; Wolf, M.; Wagner, K.V.; Liebl, C.; Scharf, S.H.; Harbich, D.; Mayer, B.; Wurst, W.; Holsboer, F.; et al. Forebrain CRHR1 deficiency attenuates chronic stress-induced cognitive deficits and dendritic remodeling. Neurobiol. Dis. 2011, 42, 300-310. [CrossRef] [PubMed]

75. Fonken, L.K.; Finy, M.S.; Walton, J.C.; Weil, Z.M.; Workman, J.L.; Ross, J.; Nelson, R.J. Influence of light at night on murine anxiety- and depressive-like responses. Behav. Brain Res. 2009, 205, 349-354. [CrossRef] [PubMed]

76. Fonken, L.K.; Kitsmiller, E.; Smale, L.; Nelson, R.J. Dim nighttime light impairs cognition and provokes depressive-like responses in a diurnal rodent. J. Biol. Rhythm. 2012, 27, 319-327. [CrossRef] [PubMed]

77. Castro, J.P.; Frussa-Filho, R.; Fukushiro, D.F.; Chinen, C.C.; Abilio, V.C.; Silva, R.H. Effects of long-term continuous exposure to light on memory and anxiety in mice. Physiol. Behav. 2005, 86, 218-223. [CrossRef] [PubMed] 
78. Craig, L.A.; McDonald, R.J. Chronic disruption of circadian rhythms impairs hippocampal memory in the rat. Brain Res. Bull. 2008, 76, 141-151. [CrossRef] [PubMed]

79. Van Donkelaar, E.L.; Vaessen, K.R.; Pawluski, J.L.; Sierksma, A.S.; Blokland, A.; Canete, R.; Steinbusch, H.W. Long-term corticosterone exposure decreases insulin sensitivity and induces depressive-like behaviour in the C57BL/6NCrl mouse. PLoS ONE 2014, 9, e106960. [CrossRef] [PubMed]

80. Wong, E.Y.; Herbert, J. Raised circulating corticosterone inhibits neuronal differentiation of progenitor cells in the adult hippocampus. Neuroscience 2006, 137, 83-92. [CrossRef] [PubMed]

81. Sapolsky, R.M.; Uno, H.; Rebert, C.S.; Finch, C.E. Hippocampal damage associated with prolonged glucocorticoid exposure in primates. J. Neurosci. 1990, 10, 2897-2902. [CrossRef] [PubMed]

82. Skorzewska, A.; Lehner, M.; Wislowska-Stanek, A.; Krzascik, P.; Ziemba, A.; Plaznik, A. The effect of chronic administration of corticosterone on anxiety- and depression-like behavior and the expression of GABA-A receptor alpha-2 subunits in brain structures of low- and high-anxiety rats. Horm. Behav. 2014, 65, 6-13. [CrossRef] [PubMed]

83. Andres, S.; Cardenas, S.; Parra, C.; Bravo, J.; Greiner, M.; Rojas, P.; Morales, P.; Lara, H.; Fiedler, J. Effects of long-term adrenalectomy on apoptosis and neuroprotection in the rat hippocampus. Endocrine 2006, 29, 299-307. [CrossRef]

84. Liu, B.; Zhang, H.; Xu, C.; Yang, G.; Tao, J.; Huang, J.; Wu, J.; Duan, X.; Cao, Y.; Dong, J. Neuroprotective effects of icariin on corticosterone-induced apoptosis in primary cultured rat hippocampal neurons. Brain Res. 2011, 1375, 59-67. [CrossRef] [PubMed]

85. Sturm, M.; Becker, A.; Schroeder, A.; Bilkei-Gorzo, A.; Zimmer, A. Effect of chronic corticosterone application on depression-like behavior in C57BL/6N and C57BL/6J mice. Genes Brain Behav. 2015, 14, 292-300. [CrossRef] [PubMed]

86. Mekiri, M.; Gardier, A.M.; David, D.J.; Guilloux, J.P. Chronic Corticosterone Administration Effects on Behavioral Emotionality in Female C57BL6 Mice. Exp. Clin. Psychopharmacol. 2017, 25, 94-104. [CrossRef] [PubMed]

87. Glover, V.; O'Connor, T.G.; O'Donnell, K. Prenatal stress and the programming of the HPA axis. Neurosci. Biobehav. Rev. 2010, 35, 17-22. [CrossRef] [PubMed]

88. Abbott, P.W.; Gumusoglu, S.B.; Bittle, J.; Beversdorf, D.Q.; Stevens, H.E. Prenatal stress and genetic risk: How prenatal stress interacts with genetics to alter risk for psychiatric illness. Psychoneuroendocrinology 2018, 90, 9-21. [CrossRef] [PubMed]

89. Kapoor, A.; Dunn, E.; Kostaki, A.; Andrews, M.H.; Matthews, S.G. Fetal programming of hypothalamopituitary-adrenal function: Prenatal stress and glucocorticoids. J. Physiol. 2006, 572, 31-44. [CrossRef] [PubMed]

90. Pechtel, P.; Pizzagalli, D.A. Effects of early life stress on cognitive and affective function: An integrated review of human literature. Psychopharmacology 2011, 214, 55-70. [CrossRef] [PubMed]

91. McEwen, B.S. Brain on stress: How the social environment gets under the skin (vol 109, pg 17180, 2012). Proc. Natl. Acad. Sci. USA 2013, 110, 1561. [CrossRef] [PubMed]

92. Hackman, D.A.; Farah, M.J.; Meaney, M.J. Science and society socioeconomic status and the brain: Mechanistic insights from human and animal research. Nat. Rev. Neurosci. 2010, 11, 651-659. [CrossRef] [PubMed]

93. Van Harmelen, A.-L.; van Tol, M.-J.; Demenescu, L.R.; van der Wee, N.J.A.; Veltman, D.J.; Aleman, A.; van Buchem, M.A.; Spinhoven, P.; Penninx, B.W.J.H.; Elzinga, B.M. Enhanced amygdala reactivity to emotional faces in adults reporting childhood emotional maltreatment. Soc. Cogn. Affect. Neurosci. 2013, 8, 362-369. [CrossRef] [PubMed]

94. Carr, C.P.; Severi Martins, C.M.; Stingel, A.M.; Lemgruber, V.B.; Juruena, M.F. The role of early life stress in adult psychiatric disorders a systematic review according to childhood trauma subtypes. J. Nerv. Ment. Dis. 2013, 201, 1007-1020. [CrossRef] [PubMed]

95. Lehmann, J.; Feldon, J. Long-term biobehavioral effects of maternal separation in the rat: Consistent or confusing? Rev. Neurosci. 2000, 11, 383-408. [CrossRef] [PubMed]

96. Hilakivi-Clarke, L.A.; Turkka, J.; Lister, R.G.; Linnoila, M. Effects of early postnatal handling on brain beta-adrenoceptors and behavior in tests related to stress. Brain Res. 1991, 542, 286-292. [CrossRef] 
97. Suri, D.; Veenit, V.; Sarkar, A.; Thiagarajan, D.; Kumar, A.; Nestler, E.J.; Galande, S.; Vaidya, V.A. Early stress evokes age-dependent biphasic changes in hippocampal neurogenesis, BDNF expression, and cognition. Biol. Psychiatry 2013, 73, 658-666. [CrossRef] [PubMed]

98. Wiener, S.G.; Levine, S. Perinatal malnutrition and early handling: Interactive effects on the development of the pituitary-adrenal system. Dev. Psychobiol. 1978, 11, 335-352. [CrossRef] [PubMed]

99. Wiener, S.G.; Levine, S. Influence of perinatal malnutrition and early handling on the pituitary-adrenal response to noxious stimuli in adult rats. Physiol. Behav. 1983, 31, 285-291. [CrossRef]

100. Schmidt, M.V.; Oitzl, M.S.; Levine, S.; de Kloet, E.R. The HPA system during the postnatal development of CD1 mice and the effects of maternal deprivation. Dev. Brain Res. 2002, 139, 39-49. [CrossRef]

101. Lehmann, J.; Russig, H.; Feldon, J.; Pryce, C.R. Effect of a single maternal separation at different pup ages on the corticosterone stress response in adult and aged rats. Pharmacol. Biochem. Behav. 2002, 73, 141-145. [CrossRef]

102. Plotsky, P.M.; Meaney, M.J. Early, postnatal experience alters hypothalamic corticotropin-releasing factor (CRF) mRNA, median eminence CRF content and stress-induced release in adult rats. Mol. Brain Res. 1993, 18, 195-200. [CrossRef]

103. Silveira, P.P.; Portella, A.K.; Benetti, C.D.; Zugno, A.I.; Scherer, E.B.D.; Mattos, C.B.; Wyse, A.T.S.; Lucion, A.B.; Dalmaz, C. Association between $\mathrm{Na}^{+}, \mathrm{K}^{+}$-atpase activity and the vulnerability/resilience to mood disorders induced by early life experience. Neurochem. Res. 2011, 36, 2075-2082. [CrossRef] [PubMed]

104. Lupien, S.J.; Parent, S.; Evans, A.C.; Tremblay, R.E.; Zelazo, P.D.; Corbo, V.; Pruessner, J.C.; Seguin, J.R. Larger amygdala but no change in hippocampal volume in 10-year-old children exposed to maternal depressive symptomatology since birth. Proc. Natl. Acad. Sci. USA 2011, 108, 14324-14329. [CrossRef] [PubMed]

105. Van Harmelen, A.L.; de Jong, P.J.; Glashouwer, K.A.; Spinhoven, P.; Penninx, B.; Elzinga, B.M. Child abuse and negative explicit and automatic self-associations: The cognitive scars of emotional maltreatment. Behav. Res. Ther. 2010, 48, 486-494. [CrossRef] [PubMed]

106. Perez-Cerezales, S.; Ramos-Ibeas, P.; Rizos, D.; Lonergan, P.; Bermejo-Alvarez, P.; Gutierrez-Adan, A. Early sex-dependent differences in response to environmental stress. Reproduction 2018, 155, R39-R51. [CrossRef] [PubMed]

107. Porsolt, R.D.; Le Pichon, M.; Jalfre, M. Depression: A new animal model sensitive to antidepressant treatments. Nature 1977, 266, 730-732. [CrossRef] [PubMed]

108. Greenberg, M.E.; Xu, B.J.; Lu, B.; Hempstead, B.L. New insights in the biology of BDNF synthesis and release: Implications in CNS function. J. Neurosci. 2009, 29, 12764-12767. [CrossRef] [PubMed]

109. Wong, J.; Hyde, T.M.; Cassano, H.L.; Deep-Soboslay, A.; Kleinman, J.E.; Weickert, C.S. Promoter specific alterations of brain-derived neurotrophic factor mRNA in schizophrenia. Neuroscience 2010, 169, 1071-1084. [CrossRef] [PubMed]

110. Lee, B.H.; Kim, Y.K. Reduced platelet bdnf level in patients with major depression. Prog. Neuro-Psychopharmacol. Biol. Psychiatry 2009, 33, 849-853. [CrossRef] [PubMed]

111. Gupta, A.; Mayer, E.A.; Acosta, J.R.; Hamadani, K.; Torgerson, C.; van Horn, J.D.; Chang, L.; Naliboff, B.; Tillisch, K.; Labus, J.S. Early adverse life events are associated with altered brain network architecture in a sex-dependent manner. Neurobiol. Stress 2017, 7, 16-26. [CrossRef] [PubMed]

112. McCutcheon, J.E.; Marinelli, M. Age matters. Eur. J. Neurosci. 2009, 29, 997-1014. [CrossRef] [PubMed]

113. Vanderkolk, B.A. Adolescent vulnerability to posttraumatic stress disorder Psychiatry-Interpers. Biol. Process. 1985, 48, 365-370.

114. Morrison, K.E.; Epperson, C.N.; Sammel, M.D.; Ewing, G.; Podcasy, J.S.; Hantsoo, L.; Kim, D.R.; Bale, T.L. Preadolescent adversity programs a disrupted maternal stress reactivity in humans and mice. Biol. Psychiatry 2017, 81, 693-701. [CrossRef] [PubMed]

115. Bale, T.L. Epigenetic and transgenerational reprogramming of brain development. Nat. Rev. Neurosci. 2015, 16, 332-344. [CrossRef] [PubMed]

116. Bale, T.L. Lifetime stress experience: Transgenerational epigenetics and germ cell programming. Dialogues Clin. Neurosci. 2014, 16, 297-305. [PubMed]

117. Roberts, A.L.; Lyall, K.; Rich-Edwards, J.W.; Ascherio, A.; Weisskopf, M.G. Association of maternal exposure to childhood abuse with elevated risk for autism in offspring. JAMA Psychiatry 2013, 70, 508-515. [CrossRef] [PubMed] 
118. Roberts, A.L.; Liew, Z.; Lyall, K.; Ascherio, A.; Weisskopf, M.G. Association of maternal exposure to childhood abuse with elevated risk for attention deficit hyperactivity disorder in offspring. Am. J. Epidemiol. 2018. [CrossRef] [PubMed]

119. Romeo, R.D. Pubertal maturation and programming of hypothalamic-pituitary-adrenal reactivity. Front. Neuroendocrinol. 2010, 31, 232-240. [CrossRef] [PubMed]

120. Cyranowski, J.M.; Frank, E.; Young, E.; Shear, M.K. Adolescent onset of the gender difference in lifetime rates of major depression: A theoretical model. Arch. Gen. Psychiatry 2000, 57, 21-27. [CrossRef] [PubMed]

121. Romeo, R.D.; Patel, R.; Pham, L.; So, V.M. Adolescence and the ontogeny of the hormonal stress response in male and female rats and mice. Neurosci. Biobehav. Rev. 2016, 70, 206-216. [CrossRef] [PubMed]

122. Blakemore, S.-J.; Burnett, S.; Dahl, R.E. The role of puberty in the developing adolescent brain. Hum. Brain Mapp. 2010, 31, 926-933. [CrossRef] [PubMed]

123. Schneider, M.; Schoemig, E.; Leweke, F.M. Acute and chronic cannabinoid treatment differentially affects recognition memory and social behavior in pubertal and adult rats. Addict. Biol. 2008, 13, 345-357. [CrossRef] [PubMed]

124. Fernandez-Fernandez, R.; Navarro, V.M.; Barreiro, M.L.; Vigo, E.M.; Tovar, S.; Sirotkin, A.V.; Casanueva, F.F.; Aguilar, E.; Dieguez, C.; Pinilla, L.; et al. Effects of chronic hyperghrelinemia on puberty onset and pregnancy outcome in the rat. Endocrinology 2005, 146, 3018-3025. [CrossRef] [PubMed]

125. Schneider, M. Adolescence as a vulnerable period to alter rodent behavior. Cell Tissue Res. 2013, 354, 99-106. [CrossRef] [PubMed]

126. Adamec, R.E.; Shallow, T. Lasting effects on rodent anxiety of a single exposure to a cat. Physiol. Behav. 1993, 54, 101-109. [CrossRef]

127. Adamec, R. Transmitter systems involved in neural plasticity underlying increased anxiety and defenseImplications for understanding anxiety following traumatic stress. Neurosci. Biobehav. Rev. 1997, 21, 755-765. [CrossRef]

128. Blanchard, D.C.; Blanchard, R.J. Ethoexperimental approaches to the biology of emotion. Annu. Rev. Psychol. 1988, 39, 43-68. [CrossRef] [PubMed]

129. Cantor, C. Post-traumatic stress disorder: Evolutionary perspectives. Aust. N. Z. J. Psychiatry 2009, 43, 1038-1048. [CrossRef] [PubMed]

130. Kessler, R.C.; Davis, C.G.; Kendler, K.S. Childhood adversity and adult psychiatric disorder in the US National Comorbidity Survey. Psychol. Med. 1997, 27, 1101-1119. [CrossRef] [PubMed]

131. McCormick, C.M.; Nixon, F.; Thomas, C.; Lowie, B.; Dyck, J. Hippocampal cell proliferation and spatial memory performance after social instability stress in adolescence in female rats. Behav. Brain Res. 2010, 208, 23-29. [CrossRef] [PubMed]

132. Miller, A.H.; Raison, C.L. The role of inflammation in depression: From evolutionary imperative to modern treatment target. Nat. Rev. Immunol. 2016, 16, 22-34. [CrossRef] [PubMed]

133. Gordon, J.A. Oscillations and hippocampal-prefrontal synchrony. Curr. Opin. Neurobiol. 2011, $21,486-491$. [CrossRef] [PubMed]

134. Oitzl, M.S.; Champagne, D.L.; van der Veen, R.; de Kloet, E.R. Brain development under stress: Hypotheses of glucocorticoid actions revisited. Neurosci. Biobehav. Rev. 2010, 34, 853-866. [CrossRef] [PubMed]

135. Broadbent, N.J.; Squire, L.R.; Clark, R.E. Spatial memory, recognition memory, and the hippocampus. Proc. Natl. Acad. Sci. USA 2004, 101, 14515-14520. [CrossRef] [PubMed]

136. Braff, D.L.; Geyer, M.A. Sensorimotor gating and schizophrenia. Human and animal model studies. Arch. Gen. Psychiatry 1990, 47, 181-188. [CrossRef] [PubMed]

137. Klug, M.; Hill, R.A.; Choy, K.H.C.; Kyrios, M.; Hannan, A.J.; van den Buuse, M. Long-term behavioral and NMDA receptor effects of young-adult corticosterone treatment in BDNF heterozygous mice. Neurobiol. Dis. 2012, 46, 722-731. [CrossRef] [PubMed]

138. Hill, R.A.; Von Soly, S.K.; Ratnayake, U.; Klug, M.; Binder, M.D.; Hannan, A.J.; van den Buuse, M. Long-term effects of combined neonatal and adolescent stress on brain-derived neurotrophic factor and dopamine receptor expression in the rat forebrain. Biochim. Biophys. Acta-Mol. Basis Dis. 2014, 1842, $2126-2135$. [CrossRef] [PubMed]

139. McCormick, C.M.; Mathews, I.Z. Adolescent development, hypothalamic-pituitary-adrenal function, and programming of adult learning and memory. Prog. Neuro-Psychopharmacol. Biol. Psychiatry 2010, 34, 756-765. [CrossRef] [PubMed] 
140. Campos, A.C.; Fogaca, M.V.; Aguiar, D.C.; Guimaraes, F.S. Animal models of anxiety disorders and stress. Rev. Bras. Psiquiatr. 2013, 35, S101-S111. [CrossRef] [PubMed]

141. Hedges, D.W.; Woon, F.L. Early-life stress and cognitive outcome. Psychopharmacology 2011, 214, 121-130. [CrossRef] [PubMed]

142. Sommershof, A.; Aichinger, H.; Engler, H.; Adenauer, H.; Catani, C.; Boneberg, E.M.; Elbert, T.; Groettrup, M.; Kolassa, I.T. Substantial reduction of naive and regulatory T cells following traumatic stress. Brain Behav. Immun. 2009, 23, 1117-1124. [CrossRef] [PubMed]

143. Jung, Y.H.; Hong, S.I.; Ma, S.X.; Hwang, J.Y.; Kim, J.S.; Lee, J.H.; Seo, J.Y.; Lee, S.Y.; Jang, C.G. Strain differences in the chronic mild stress animal model of depression and anxiety in mice. Biomol. Ther. 2014, 22, 453-459. [CrossRef] [PubMed]

144. Troop, N.A.; Hiskey, S. Social defeat and PTSD symptoms following trauma. Br. J. Clin. Psychol. 2013, 52, 365-379. [CrossRef] [PubMed]

145. Takahashi, L.K.; Nakashima, B.R.; Hong, H.; Watanabe, K. The smell of danger: A behavioral and neural analysis of predator odor-induced fear. Neurosci. Biobehav. Rev. 2005, 29, 1157-1167. [CrossRef] [PubMed]

146. Campeau, S.; Nyhuis, T.J.; Sasse, S.K.; Day, H.E.; Masini, C.V. Acute and chronic effects of ferret odor exposure in sprague-dawley rats. Neurosci. Biobehav. Rev. 2008, 32, 1277-1286. [CrossRef] [PubMed]

147. Takahashi, L.K. Olfactory systems and neural circuits that modulate predator odor fear. Front. Behav. Neurosci. 2014, 8, 72. [CrossRef] [PubMed]

148. Apfelbach, R.; Blanchard, C.D.; Blanchard, R.J.; Hayes, R.A.; McGregor, I.S. The effects of predator odors in mammalian prey species: A review of field and laboratory studies. Neurosci. Biobehav. Rev. 2005, 29, 1123-1144. [CrossRef] [PubMed]

149. Adamec, R.E.; Burton, P.; Shallow, T.; Budgell, J. Nmda receptors mediate lasting increases in anxiety-like behavior produced by the stress of predator exposure-implications for anxiety associated with posttraumatic stress disorder. Physiol. Behav. 1999, 65, 723-737. [CrossRef]

150. Campos, A.C.; Ferreira, F.R.; da Silva, W.A., Jr.; Guimaraes, F.S. Predator threat stress promotes long lasting anxiety-like behaviors and modulates synaptophysin and CB1 receptors expression in brain areas associated with PTSD symptoms. Neurosci. Lett. 2013, 533, 34-38. [CrossRef] [PubMed]

151. Staples, L.G.; McGregor, I.S.; Hunt, G.E. Long-lasting FosB/DeltaFosB immunoreactivity in the rat brain after repeated cat odor exposure. Neurosci. Lett. 2009, 462, 157-161. [CrossRef] [PubMed]

152. Janitzky, K.; Peine, A.; Krober, A.; Yanagawa, Y.; Schwegler, H.; Roskoden, T. Increased CRF mRNA expression in the sexually dimorphic BNST of male but not female GAD67 mice and TMT predator odor stress effects upon spatial memory retrieval. Behav. Brain Res. 2014, 272, 141-149. [CrossRef] [PubMed]

153. Jagannath, A.; Peirson, S.N.; Foster, R.G. Sleep and circadian rhythm disruption in neuropsychiatric illness. Curr. Opin. Neurobiol. 2013, 23, 888-894. [CrossRef] [PubMed]

154. Sapolsky, R.M. Glucocorticoid toxicity in the hippocampus. Temporal aspects of synergy with kainic acid. Neuroendocrinology 1986, 43, 440-444. [CrossRef] [PubMed]

155. Cook, S.C.; Wellman, C.L. Chronic stress alters dendritic morphology in rat medial prefrontal cortex. J. Neurobiol. 2004, 60, 236-248. [CrossRef] [PubMed]

156. Hauer, D.; Weis, F.; Krauseneck, T.; Vogeser, M.; Schelling, G.; Roozendaal, B. Traumatic memories, post-traumatic stress disorder and serum cortisol levels in long-term survivors of the acute respiratory distress syndrome. Brain Res. 2009, 1293, 114-120. [CrossRef] [PubMed]

157. Aerni, A.; Traber, R.; Hock, C.; Roozendaal, B.; Schelling, G.; Papassotiropoulos, A.; Nitsch, R.M.; Schnyder, U.; de Quervain, D.J. Low-dose cortisol for symptoms of posttraumatic stress disorder. Am. J. Psychiatry 2004, 161, 1488-1490. [CrossRef] [PubMed]

158. Zohar, J.; Yahalom, H.; Kozlovsky, N.; Cwikel-Hamzany, S.; Matar, M.A.; Kaplan, Z.; Yehuda, R.; Cohen, H. High dose hydrocortisone immediately after trauma may alter the trajectory of PTSD: Interplay between clinical and animal studies. Eur. Neuropsychopharmacol. 2011, 21, 796-809. [CrossRef] [PubMed]

159. Jia, M.; Smerin, S.E.; Zhang, L.; Xing, G.; Li, X.; Benedek, D.; Ursano, R.; Li, H. Corticosterone mitigates the stress response in an animal model of PTSD. J. Psychiatr. Res. 2015, 60, 29-39. [CrossRef] [PubMed]

160. Deppermann, S.; Storchak, H.; Fallgatter, A.J.; Ehlis, A.C. Stress-induced neuroplasticity: (Mal) adaptation to adverse life events in patients with PTSD—A critical overview. Neuroscience 2014, 283, 166-177. [CrossRef] [PubMed] 
161. Way, B.M.; Taylor, S.E. The serotonin transporter promoter polymorphism is associated with cortisol response to psychosocial stress. Biol. Psychiatry 2010, 67, 487-492. [CrossRef] [PubMed]

162. Miller, R.; Wankerl, M.; Stalder, T.; Kirschbaum, C.; Alexander, N. The serotonin transporter gene-linked polymorphic region (5-HTTLPR) and cortisol stress reactivity: A meta-analysis. Mol. Psychiatry 2013, 18, 1018-1024. [CrossRef] [PubMed]

163. Caspi, A.; Hariri, A.R.; Holmes, A.; Uher, R.; Moffitt, T.E. Genetic sensitivity to the environment: The case of the serotonin transporter gene and its implications for studying complex diseases and traits. Am. J. Psychiatry 2010, 167, 509-527. [CrossRef] [PubMed]

164. Chen, F.S.; Kumsta, R.; von Dawans, B.; Monakhov, M.; Ebstein, R.P.; Heinrichs, M. Common oxytocin receptor gene (OXTR) polymorphism and social support interact to reduce stress in humans. Proc. Natl. Acad. Sci. USA 2011, 108, 19937-19942. [CrossRef] [PubMed]

165. Belay, H.; Burton, C.L.; Lovic, V.; Meaney, M.J.; Sokolowski, M.; Fleming, A.S. Early adversity and serotonin transporter genotype interact with hippocampal glucocorticoid receptor mRNA expression, corticosterone, and behavior in adult male rats. Behav. Neurosci. 2011, 125, 150-160. [CrossRef] [PubMed]

166. Petersson, M.; Uvnas-Moberg, K. Systemic oxytocin treatment modulates glucocorticoid and mineralocorticoid receptor mRNA in the rat hippocampus. Neurosci. Lett. 2003, 343, 97-100. [CrossRef]

167. Oitzl, M.S.; Kloet, E.R.; Joëls, M.; Schmid, W.; Cole, T.J. Spatial learning deficits in mice with a targeted glucocorticoid receptor gene disruption. Eur. J. Neurosci. 1997, 9, 2284-2296. [CrossRef] [PubMed]

168. Kolber, B.J.; Wieczorek, L.; Muglia, L.J. Hypothalamic-pituitary-adrenal axis dysregulation and behavioral analysis of mouse mutants with altered glucocorticoid or mineralocorticoid receptor function: Review. Stress Int. J. Biol. Stress 2008, 11, 321-338. [CrossRef] [PubMed]

169. Cole, T.J.; Blendy, J.A.; Monaghan, A.P.; Krieglstein, K.; Schmid, W.; Aguzzi, A.; Fantuzzi, G.; Hummler, E.; Unsicker, K.; Schütz, G. Targeted disruption of the glucocorticoid receptor gene blocks adrenergic chromaffin cell development and severely retards lung maturation. Genes Dev. 1995, 9, 1608-1621. [CrossRef] [PubMed]

170. Berger, S.; Bleich, M.; Schmid, W.; Cole, T.J.; Peters, J.; Watanabe, H.; Kriz, W.; Warth, R.; Greger, R.; Schütz, G. Mineralocorticoid receptor knockout mice: Pathophysiology of $\mathrm{Na}^{+}$metabolism. Proc. Natl. Acad. Sci. USA 1998, 95, 9424-9429. [CrossRef] [PubMed]

171. Gass, P.; Kretz, O.; Wolfer, D.P.; Berger, S.; Tronche, F.; Reichardt, H.M.; Kellendonk, C.; Lipp, H.P.; Schmid, W.; Schütz, G. Genetic disruption of mineralocorticoid receptor leads to impaired neurogenesis and granule cell degeneration in the hippocampus of adult mice. EMBO Rep. 2000, 1, 447-451. [CrossRef] [PubMed]

172. Schulz-Baldes, A.; Berger, S.; Grahammer, F.; Warth, R.; Goldschmidt, I.; Peters, J.; Schütz, G.; Greger, R.; Bleich, M. Induction of the epithelial $\mathrm{Na}^{+}$channel via glucocorticoids in mineralocorticoid receptor knockout mice. Pflügers Arch. 2001, 443, 297-305. [CrossRef] [PubMed]

173. Cole, T.J.; Myles, K.; Purton, J.F.; Brereton, P.S.; Solomon, N.M.; Godfrey, D.I.; Funder, J.W. Grko mice express an aberrant dexamethasone-binding glucocorticoid receptor, but are profoundly glucocorticoid resistant. Mol. Cell. Endocrinol. 2001, 173, 193-202. [CrossRef]

174. Ridder, S.; Chourbaji, S.; Hellweg, R.; Urani, A.; Zacher, C.; Schmid, W.; Zink, M.; Hörtnagl, H.; Flor, H.; Henn, F.A. Mice with genetically altered glucocorticoid receptor expression show altered sensitivity for stress-induced depressive reactions. J. Neurosci. 2005, 25, 6243-6250. [CrossRef] [PubMed]

175. Reichardt, H.M.; Umland, T.; Bauer, A.; Kretz, O.; Schütz, G. Mice with an increased glucocorticoid receptor gene dosage show enhanced resistance to stress and endotoxic shock. Mol. Cell. Biol. 2000, 20, 9009-9017. [CrossRef] [PubMed]

176. Pepin, M.; Pothier, F.; Barden, N. Antidepressant drug action in a transgenic mouse model of the endocrine changes seen in depression. Mol. Pharmacol. 1992, 42, 991-995. [PubMed]

177. Froger, N.; Palazzo, E.; Boni, C.; Hanoun, N.; Saurini, F.; Joubert, C.; Dutriez-Casteloot, I.; Enache, M.; Maccari, S.; Barden, N. Neurochemical and behavioral alterations in glucocorticoid receptor-impaired transgenic mice after chronic mild stress. J. Neurosci. 2004, 24, 2787-2796. [CrossRef] [PubMed]

178. Tronche, F.; Kellendonk, C.; Kretz, O.; Gass, P.; Anlag, K.; Orban, P.C.; Bock, R.; Klein, R.; Schütz, G. Disruption of the glucocorticoid receptor gene in the nervous system results in reduced anxiety. Nat. Genet. 1999, 23, 99-103. [CrossRef] [PubMed]

179. Deroche-Gamonet, V.; Sillaber, I.; Aouizerate, B.; Izawa, R.; Jaber, M.; Ghozland, S.; Kellendonk, C.; Le Moal, M.; Spanagel, R.; Schütz, G. The glucocorticoid receptor as a potential target to reduce cocaine abuse. J. Neurosci. 2003, 23, 4785-4790. [CrossRef] [PubMed] 
180. Revest, J.-M.; Kaouane, N.; Mondin, M.; Le Roux, A.; Rougé-Pont, F.; Vallée, M.; Barik, J.; Tronche, F.; Desmedt, A.; Piazza, P. The enhancement of stress-related memory by glucocorticoids depends on synapsin-Ia/Ib. Mol. Psychiatry 2010, 15, 1140-1151. [CrossRef] [PubMed]

181. Revest, J.-M.; Di Blasi, F.; Kitchener, P.; Rougé-Pont, F.; Desmedt, A.; Turiault, M.; Tronche, F.; Piazza, P.V. The MAPK pathway and Egr-1 mediate stress-related behavioral effects of glucocorticoids. Nat. Neurosci. 2005, 8, 664-672. [CrossRef] [PubMed]

182. Boyle, M.P.; Brewer, J.A.; Funatsu, M.; Wozniak, D.F.; Tsien, J.Z.; Izumi, Y.; Muglia, L.J. Acquired deficit of forebrain glucocorticoid receptor produces depression-like changes in adrenal axis regulation and behavior. Proc. Natl. Acad. Sci. USA 2005, 102, 473-478. [CrossRef] [PubMed]

183. Solomon, M.B.; Furay, A.R.; Jones, K.; Packard, A.E.; Packard, B.A.; Wulsin, A.C.; Herman, J.P. Deletion of forebrain glucocorticoid receptors impairs neuroendocrine stress responses and induces depression-like behavior in males but not females. Neuroscience 2012, 203, 135-143. [CrossRef] [PubMed]

184. Vincent, M.Y.; Hussain, R.J.; Zampi, M.E.; Sheeran, K.; Solomon, M.B.; Herman, J.P.; Khan, A.; Jacobson, L. Sensitivity of depression-like behavior to glucocorticoids and antidepressants is independent of forebrain glucocorticoid receptors. Brain Res. 2013, 1525, 1-15. [CrossRef] [PubMed]

185. Berger, S.; Wolfer, D.P.; Selbach, O.; Alter, H.; Erdmann, G.; Reichardt, H.M.; Chepkova, A.N.; Welzl, H.; Haas, H.L.; Lipp, H.-P. Loss of the limbic mineralocorticoid receptor impairs behavioral plasticity. Proc. Natl. Acad. Sci. USA 2006, 103, 195-200. [CrossRef] [PubMed]

186. Ter Horst, J.; Van Der Mark, M.; Arp, M.; Berger, S.; De Kloet, E.; Oitzl, M. Stress or no stress: Mineralocorticoid receptors in the forebrain regulate behavioral adaptation. Neurobiol. Learn. Mem. 2012, 98, 33-40. [CrossRef] [PubMed]

187. Ter Horst, J.P.; Kentrop, J.; Arp, M.; Hubens, C.J.; de Kloet, E.R.; Oitzl, M.S. Spatial learning of female mice: A role of the mineralocorticoid receptor during stress and the estrous cycle. Front. Behav. Neurosci. 2013, 7, 56. [CrossRef] [PubMed]

188. Reichardt, H.M.; Kaestner, K.H.; Tuckermann, J.; Kretz, O.; Wessely, O.; Bock, R.; Gass, P.; Schmid, W.; Herrlich, P.; Angel, P. DNA binding of the glucocorticoid receptor is not essential for survival. Cell 1998, 93, 531-541. [CrossRef]

189. Heck, S.; Kullmann, M.; Gast, A.; Ponta, H.; Rahmsdorf, H.; Herrlich, P.; Cato, A. A distinct modulating domain in glucocorticoid receptor monomers in the repression of activity of the transcription factor AP-1. EMBO J. 1994, 13, 4087-4095. [PubMed]

190. Oitzl, M.S.; Reichardt, H.M.; Joëls, M.; de Kloet, E.R. Point mutation in the mouse glucocorticoid receptor preventing DNA binding impairs spatial memory. Proc. Natl. Acad. Sci. 2001, 98, 12790-12795. [CrossRef] [PubMed]

191. Moser, E.; Moser, M.-B.; Andersen, P. Spatial learning impairment parallels the magnitude of dorsal hippocampal lesions, but is hardly present following ventral lesions. J. Neurosci. 1993, 13, 3916-3925. [CrossRef] [PubMed]

192. Fanselow, M.S.; Dong, H.-W. Are the dorsal and ventral hippocampus functionally distinct structures? Neuron 2010, 65, 7-19. [CrossRef] [PubMed]

193. Robertson, D.A.; Beattie, J.; Reid, I.; Balfour, D. Regulation of corticosteroid receptors in the rat brain: The role of serotonin and stress. Eur. J. Neurosci. 2005, 21, 1511-1520. [CrossRef] [PubMed]

194. Buret, L.; van den Buuse, M. Corticosterone treatment during adolescence induces down-regulation of reelin and NMDA receptor subunit GLUN2C expression only in male mice: Implications for schizophrenia. Int. J. Neuropsychopharmacol. 2014, 17, 1221-1232. [CrossRef] [PubMed]

195. Gass, P.; Reichardt, H.M.; Strekalova, T.; Henn, F.; Tronche, F. Mice with targeted mutations of glucocorticoid and mineralocorticoid receptors: Models for depression and anxiety? Physiol. Behav. 2001, 73, 811-825. [CrossRef]

(C) 2018 by the authors. Licensee MDPI, Basel, Switzerland. This article is an open access article distributed under the terms and conditions of the Creative Commons Attribution (CC BY) license (http:/ / creativecommons.org/licenses/by/4.0/). 